\title{
Endogeneity of Inflation Target
}

\author{
Soyoung Kim*, Geunhyung Yim**
}

The views expressed herein are those of the authors and do not necessarily reflect the official views of the Bank of Korea. When reporting or citing this paper, the authors' names should always be explicitly stated.

* Professor, Department of Economics, Seoul National University, Tel: +82-2-880-2689, E-mail: soyoungkim@snu.ac.kr. ** Economist, Economic Research Institute, The Bank of Korea, Tel: +82-2-759-5349, E-mail: ghyim@bok.or.kr.

The authors are grateful to Byungkuk Kim, Kiyoung Jeon, Hyunjoo Ryou, Seryung Park, and other anonymous referees for their valuable comments for this paper. 


\section{Contents}

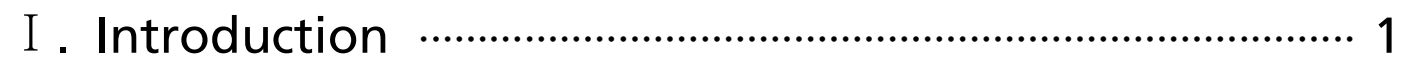

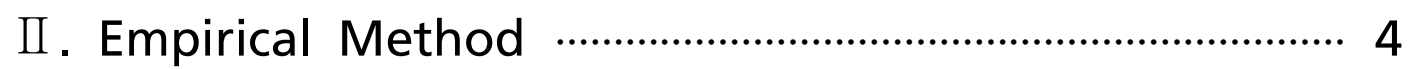

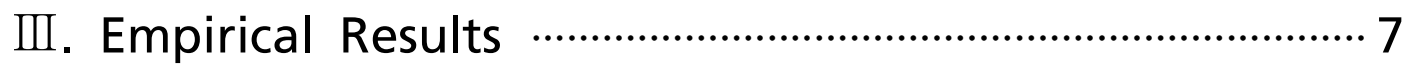

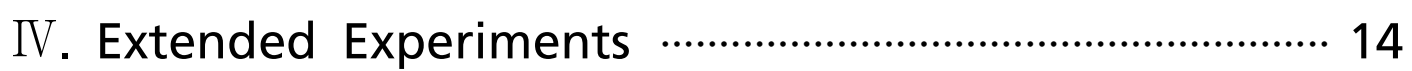

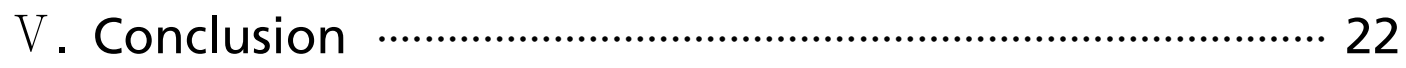

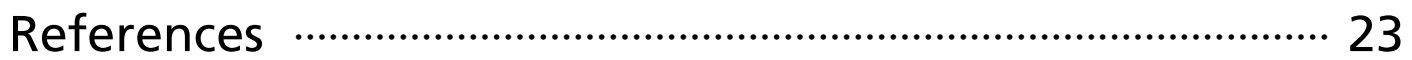

Appendix 


\section{Endogeneity of Inflation Target}

Under inflation targeting, central banks set an inflation target in advance and then try to make an actual inflation hit the target. However, central banks may have an incentive to adjust the target to actual inflation rates such as past inflation rates, to make the actual inflation rate close to the target. This paper examines this issue of "endogeneity of inflation target" by using various empirical methods with the sample of 19 inflation targeting countries. Empirical results show that an inflation rate has significantly positive effect on the inflation target of the next period. Empirical results further suggest that this endogeneity of the inflation target is found more strongly in central banks with low credibility or weak performance than in central banks with high credibility or strong performance.

Keywords: Inflation targeting, Inflation rate, Inflation target, Endogeneity

JEL Classification: E31, E58 


\section{I . Introduction}

Since New Zealand adopted inflation targeting in 1990, more and more countries have joined to adopt inflation targeting. In many countries, even in emerging countries, actual inflation rates dropped sharply after introducing inflation targeting. By now, more than 30 countries have adopted inflation targeting.

However, some previous studies have challenged the success story of inflation targeting, by arguing that the adoption of inflation targeting is an endogenous choice. Ball and Sheridan (2005), in a debate on the evaluation of the macroeconomic performance of the inflation targeting system, pay attention to the fact that the inflation levels of inflation targeting adopters were relatively higher than those of non-adopters during the preinflation targeting period. Based on this observation, they claim that stabilizing effects from the adoption of inflation targeting argued by Bernanke et al. (1999) were likely to be a "regression to the mean" phenomenon in fact. That is, the inflation level decreased and the real GDP volatility reduced in countries that adopted inflation targeting, but it was a mere reaction to the high inflation of the pre-inflation targeting period. That is, higher inflation resulted in the adoption of the inflation targeting system on the one hand and the lower inflation and stable output during the inflation targeting period on the other hand. Ball and Sheridan (2005) show that there was no evidence of a causal relation from the adoption of inflation targeting to better economic performance in case the decision on the adoption of inflation targeting was made endogenously. Following the study of Ball and Sheridan (2005), many studies have investigated this endogeneity issue when measuring the performance of inflation targeting (Uhlig, 2004; Mishikin and Schmidt-Hebbel, 2002; Gertler, 2005; Mishkin, 2005; Mishkin and Schmidt-Hebbel, 2006).1)

1) To resolve this endogeneity issue, a variety of methodologies such as difference in difference method (Cecchetti and Ehrmann (2000), Hu (2003), Neumann and von Hagen (2002)), controlling for initial conditions (Ball and Sheridan (2005), Gonçalvez and Salles (2008)), instrumental variable approach (Mishkin and Schmidt-Hebbel (2007)), and propensity score matching (Lin and Ye (2007, 2009), Vega and Winkelried (2005)) have been tried. For a survey of literature, refer to Svensson (2011). 
This paper brings attention to another type of endogeneity issue in relation to inflation targeting. While previous studies have discussed the endogeneity of the adoption of inflation targeting, this paper analyzes the endogeneity of an inflation target itself under inflation targeting. That is, a central bank under inflation targeting may adjust its inflation target endogenously to the state of the economy, in particular, past inflation rates. ${ }^{2)}$

For example, the Bank of Indonesia set a three-year inflation target in 2004: as $6 \pm 1 \%$ in $2005,5.5 \pm 1 \%$ in 2006, and $5 \pm 1 \%$ in 2007. But when the inflation rate increased more than expected $(10.5 \%$ in 2005), the Bank of Indonesia adjusted the target in 2005 , to $8 \pm 1 \%$ in $2006,6 \pm 1 \%$ in 2007 , and $5 \pm 1 \%$ in 2008 .

As another example, the central bank of Colombia decreased the annual inflation target from $22 \%$ (1993) to $19 \%$ (1994), 18\% (1995), and 17\% (1996), as the inflation rate decreased from $27 \%$ in 1992 to $22.5 \%$ in $1993,22.8 \%$ in 1994 , and $20.9 \%$ in 1995 . However, as the inflation rate did not fall much in 1996 (20.8\%), the central bank increased the target for 1997 to $18 \%$. Then, the inflation rate did drop to $18.5 \%$ in 1997 , and accordingly the central bank decreased the target for 1998 to $16 \%$. Further, as the inflation rate dropped from $18.7 \%$ (in 1998) to $10.9 \%$ (in 1999), the bank again lowered the target from $15 \%$ (1999) to $10 \%$ (2000). Even in more recent years, the central bank of Colombia adjusted the target rate due to changes in inflation rates. As the inflation rate increased sharply from $5.5 \%$ in 2007 to $7 \%$ in 2008, the central bank raised the target from $3.5 \sim 4.5 \%$ (2008) to $4.5 \sim 5.5 \%$ (2009). Then, the inflation rate dropped in 2009 (4.2\%), and subsequently the target for 2010 decreased to $3 \pm 1 \%$. In fact, the correlation between the inflation target and the lagged inflation rate in Colombia is 1.

There can be various reasons for such endogeneity. For example, under inflation targeting, central banks often face huge pressures on keeping an actual

2) In principle, from the monetarist's viewpoint, there is no need for the inflation target to be dependent upon any economic fundamentals (Anderson et al. (2014)). 
inflation rate within a target range. With such pressures, when an actual inflation rate deviates from an inflation target, central banks may decide to change the inflation target itself to close the gap between the inflation target and actual inflation rate. In other words, central banks ideally set an inflation target first, and then an actual inflation rate is supposed to be adjusted to the target, if successful. Instead, central banks may adjust an inflation target to an actual inflation rate, especially when it is difficult to make the actual inflation rate meet the target. With such endogeneity, inflation targeting may look successful even when it is not. In addition, such endogeneity may weaken the stabilizing role of inflation targeting. Inflation targeting is expected to help stabilize inflation by setting the target, trying to achieve the target, showing such efforts of central banks to economic agents, and leading economic agents to set inflation expectations close to the target. However, if central banks change the target according to past inflation rates or inflation expectations, inflation expectations of economic agents and actual inflation rates may not be stabilized. ${ }^{3}$ )

In this paper, we investigate whether an actual inflation rate affects a future inflation target or whether an inflation target is influenced by past actual inflation rates, by examining 19 inflation targeting countries. We perform the Granger causality test and draw scatter plots for individual countries and run panel regressions as a more formal analysis. The analysis implies that past inflation rates have a significant influence on the inflation target of the next period. That is, there exists endogeneity when central banks set their inflation targets. These results are robust to various modifications of the model, for example, considering the reverse causality and reducing the sample period. We also divide the sample countries into two groups by to what extent each central bank achieved the inflation target: high vs. low performance groups. Then, we

3) If the Phillips curve is non-linear, the sacrifice ratio is dependent upon the level of the inflation rate. In this case, if a central bank considers the sacrifice ratio when setting an inflation target, the decision on the inflation target may reflect the inflation performance of the economy. Some DSGE literature models time-varying inflation target assuming that a central bank changes its target as it learns the structure of the economy such as output-inflation trade-off. See Cogley et al. (2010). 
perform the previous analysis for each group. The result shows that the low performance group much more actively adjust inflation targets to the past level than high performance group. This may suggest that central banks with low performance have more incentive to adjust an inflation target close to the past inflation rate to minimize the gap between actual inflation and the target.

The rest of this paper is organized as follows. In Section 2, we explain the empirical methodology. In Section 3, we present the empirical results. In Section 4, we conduct various extended analyses. In Section 5, we conclude with a summary of the results.

\section{Empirical Method}

\section{Data}

As of April 2015, 32 countries are explicitly adopting inflation targeting as the monetary policy regime. Among them, we exclude seven countries that have made an inflation target decision no more than once and six countries that have adopted inflation targeting only recently, say after the 2008 09 global financial crisis. By excluding these 13 countries, we end up with 19 countries, to analyze the relation between an inflation target and past inflation rates. ${ }^{4)}$ Those 19 countries are Brazil, Canada, Chile, Colombia, Czech Republic, Ghana, Guatemala, Hungary, Indonesia, Israel, Korea, Mexico, New Zealand, Peru, the Philippines, Poland, Romania, Thailand, and Turkey. In terms of the sample period, we include not only the explicit but also implicit targeting period, since the explicit inflation targeting period is often short and we also want to see the overall experience of inflation targeting. In Section 4, we conduct an analysis with the sample of only explicit targeting periods, to check the robustness of our main results.5)

4) The former case includes Armenia, Australia, Iceland, Norway, South Africa, Sweden, United Kingdom while the latter case includes Albania, Georgia, India, Japan, Moldova, Serbia. 
We use the inflation rate and inflation target data of 19 countries. The IMF's International Financial Statistics (IFS) is the main source of our inflation rate data but we also collect the data from each central bank's web pages since some data such as core CPI is hard to obtain from IFS. We acquire inflation target data mainly from each central bank's web pages, but some omitted values are collected from IMF country report and Mishkin and Savastano (2002).

\section{Empirical methodology}

To investigate the relation between past inflation rates and current inflation targets, we use various empirical methods. First, we examine preliminary data properties by conducting the Granger causality test for each country. Second, we report scatter plots for each country to have a rough idea of the relation. Third, we conduct the panel regression analysis to formally infer the relation.

We conduct the Granger causality test for actual inflation rates and mid-point inflation targets in each country. The inflation targeting period is considered, but there are some exceptions. For Korea, it is from 2000 to 2006 when the Bank of Korea targeted the core CPI, and for the Czech Republic, it is after 2002 as the Czech National Bank changed the target index from net CPI to headline CPI in 2002. In case of Indonesia, we analyze the period of after 2003 when monthly inflation data are available. We exclude Thailand because the Bank of Thailand first changed its mid-point inflation target in 2015. We use monthly data to secure enough degrees of freedom.

We report scatter plots for individual countries. Before conducting the main regression analysis, we would like to sketch the relationship between an actual inflation rate and inflation target in each country. Formal regression analysis for

5) Chile, Colombia, Ghana, Indonesia, Mexico, Peru, and Turkey announced the implicit inflation target because they were not sure that they have macroeconomic preconditions that were required for the successful management of inflation targeting. But in the case of Ghana, we consider only the explicit inflation targeting period because data is not available for the implicit inflation targeting period. Details on the timing of adoption and the change in the inflation target are summarized in Table A1 in the Appendix. 
individual countries would be interesting, but which is not easy only with the limited number of observations. Therefore, we report informal scatter plots for individual countries. We use annual data on inflation rates and mid-point of inflation target data of 19 countries. We use annual data, instead of monthly data, since inflation target decisions are made at best at annual frequency and we would like to infer central banks' behavior on setting inflation targets.

Scatter plots are produced in a fashion to display mid-point of inflation targets in certain periods and the inflation performance of the immediately preceding years at the same time. We consider three ways of calculating past inflation performance: the inflation rate of previous one year, the average inflation of previous two years, and the average inflation rate of previous inflation target years. For example, if the inflation target period is set for 3 years from 2013 to 2015 , the average of the mid-point of inflation target in 2013 15 is compared with the inflation rate in 2012, the average inflation rate in $2011 \sim 12$, and the average inflation rate in 2010 12, respectively. However, the length of the period of which inflation performance is measured does not exceed maximum three years.

We conduct the panel regression analysis. Three kinds of models are considered. First, we run a simple regression model where the mid-point of inflation target is a dependent variable and the past inflation rate is an explanatory variable:

$$
\pi_{-} \text {target }_{i t}=\alpha_{0}+\alpha_{1} \pi_{-} \text {past }_{i t}+\varepsilon_{i t}
$$

where $\pi_{-}$target is the mid-point value of inflation target and $\pi_{-}$past is the inflation rate in the previous period, and is an error term. The exact definitions are the same as those used in scatter plots.

Second, we extend the first model by adding the past inflation target value as an explanatory variable since central banks may take the past inflation target 
value into consideration when they set the current inflation target:

$$
\pi_{-} \text {target }_{i t}=\beta_{0}+\beta_{1} \pi_{-} \text {past }_{i t}+\beta_{2} \pi_{-} \text {target }_{i t-1}+\varepsilon_{i t}
$$

where $\pi_{-}$target $_{i t-1}$ is the past inflation target value. In equation (1), the past inflation rate may have an explanatory power even when the past target explains the current target since the past target and the past inflation rate may be correlated. In equation (2), such possibility is controlled for.

Finally, we estimate the following model to analyze whether central banks systematically adjust their inflation target when inflation rates miss the target in the previous period.

$$
\pi_{-} \text {target }_{i t}-\pi_{-} \text {target }_{i t-1}=\gamma_{0}+\gamma_{1}\left(\pi_{-} \text {past }_{i t}-\pi_{-} \text {target }_{i t-1}\right)+\varepsilon_{i t}
$$

\section{Empirical Results}

\section{Scatter plot}

The scatter plots are shown in Figure 1. In most countries, positive correlations between inflation targets and past inflation performances are observed. The correlations are negative in only three countries (Thailand, the Philippines, and New Zealand). In particular, in Israel, Poland, Chile, Colombia, Peru, Romania, and Turkey, almost one-to-one relationship is found. In addition, the sign of correlation remains unchanged and the magnitude of the correlation is similar in each country, regardless of how we measure the past inflation performance. The Philippines and Thailand are the only countries in which the signs of correlation change when we evaluate past inflation performances in different ways. 
Figure 1: Relation between Inflation Target and Past Inflation Rate

(A) Inflation Target vs, Inflation Rate in Past One Year ${ }^{1)}$
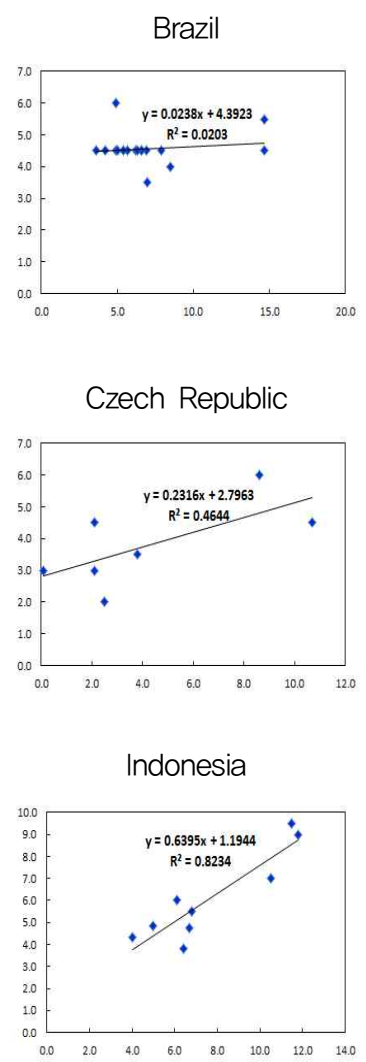

New Zealand

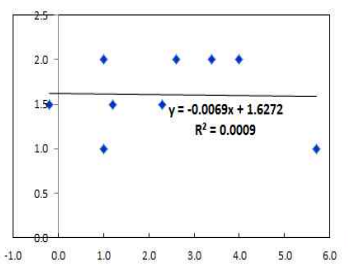

Romania

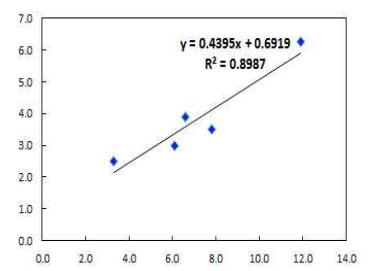

Canada

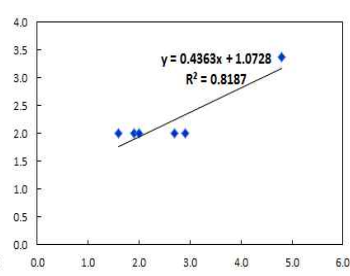

Ghana

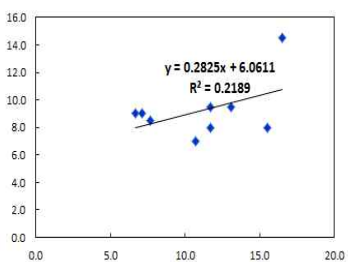

Israel

Chile

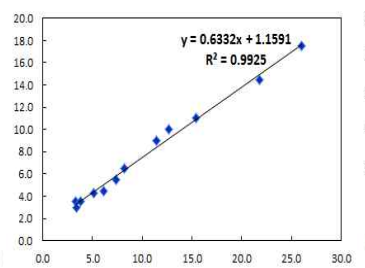

Guatemala

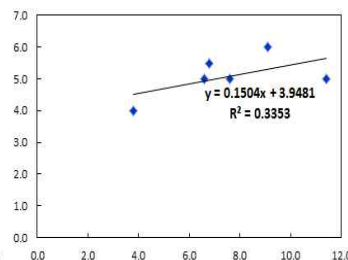

Korea

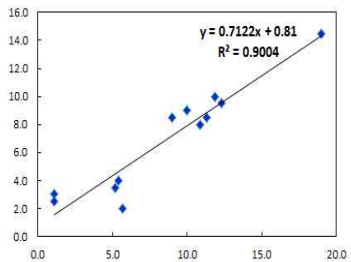

Peru

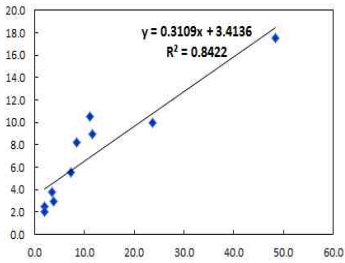

Thailand
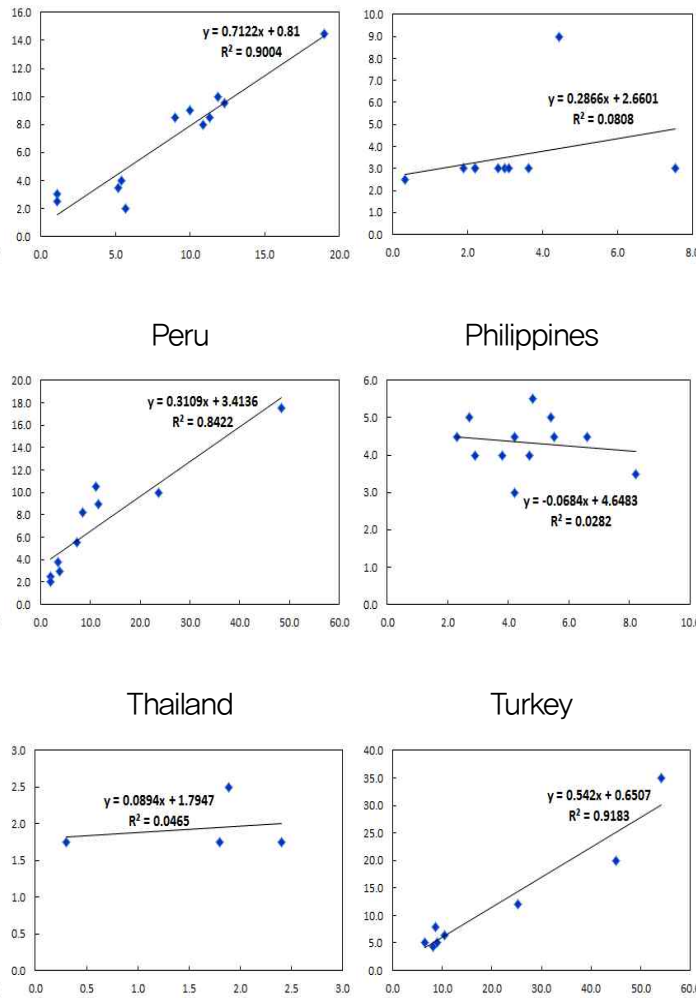

Philippines

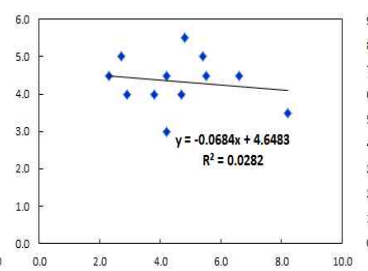

Turkey

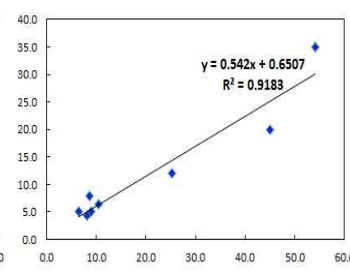

Colombia

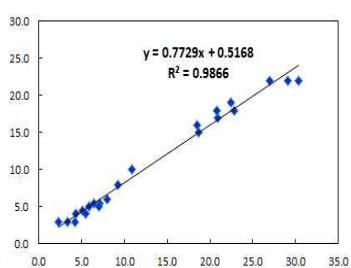

Hungary

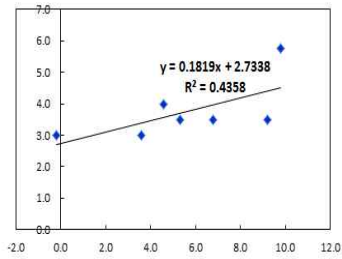

Mexico

Poland

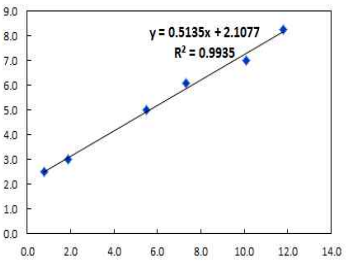

Note: 1) The horizontal axis indicates the inflation rate of previous one year and the vertical axis indicates inflation target. 
(B) Inflation Target vs. Average Inflation Rate in Past Two Year ${ }^{1)}$
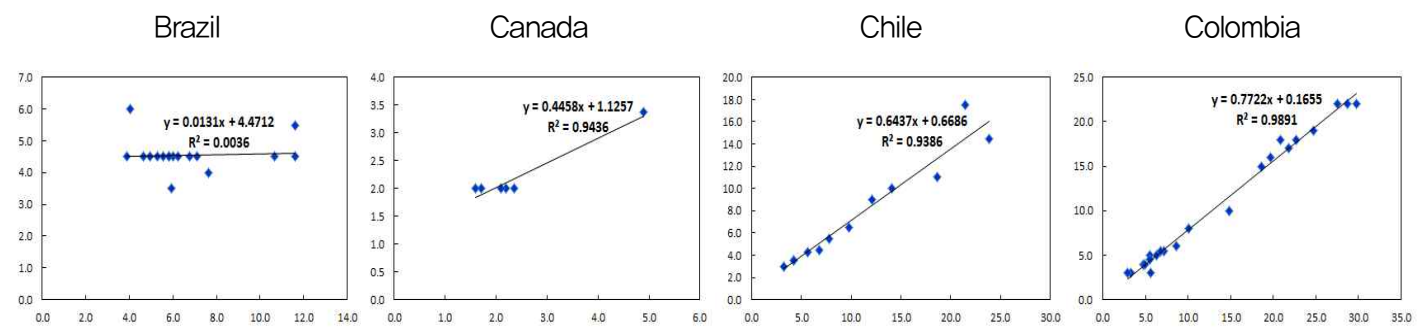

Czech Republic

Ghana

Guatemala

Hungary
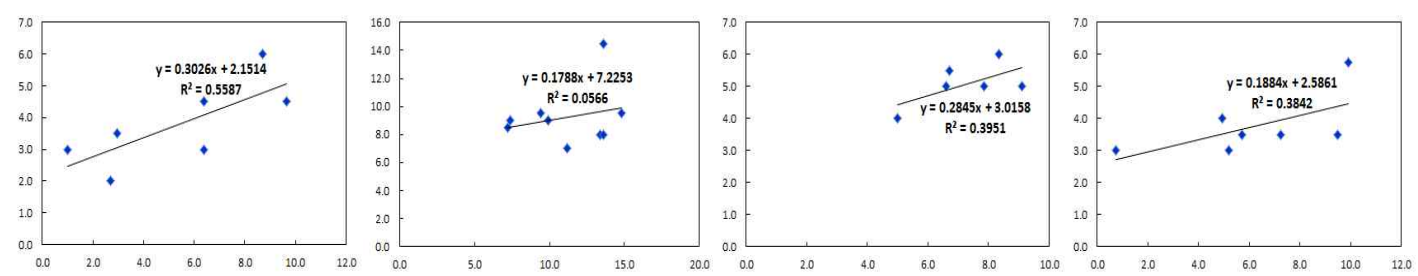

Indonesia

Israel

Korea

Mexico
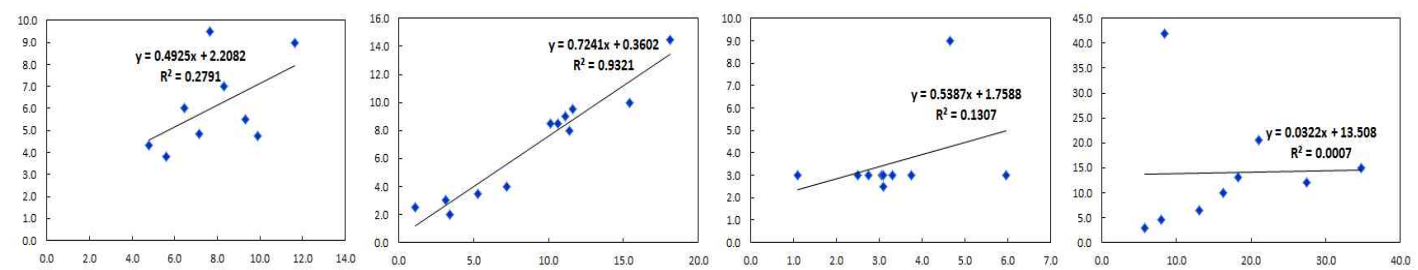

New Zealand

Peru

Philippines

Poland
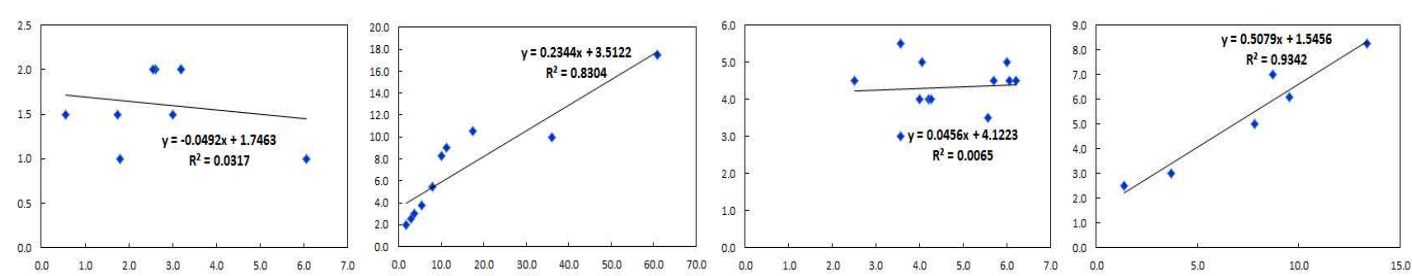

Romania

Thailand
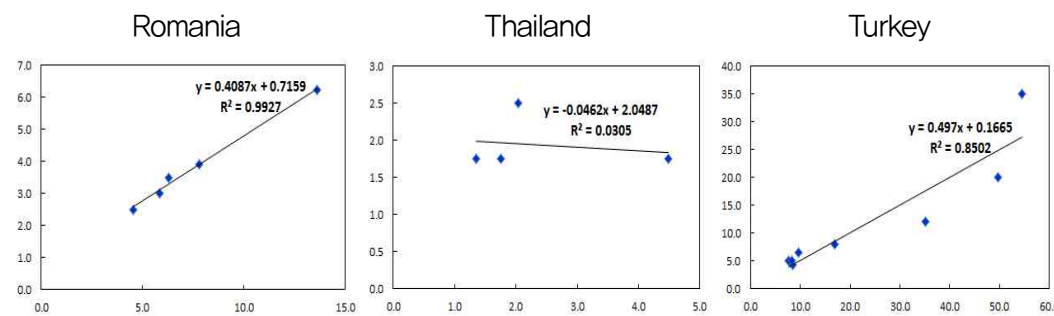

Note: 1) The horizontal axis indicates the average rate of inflation of previous two years and the vertical axis indicates inflation target. 
(C) Inflation Target vs. Average Inflation Rate in Past Target Horizon (Max 3 Years) $)^{1)}$
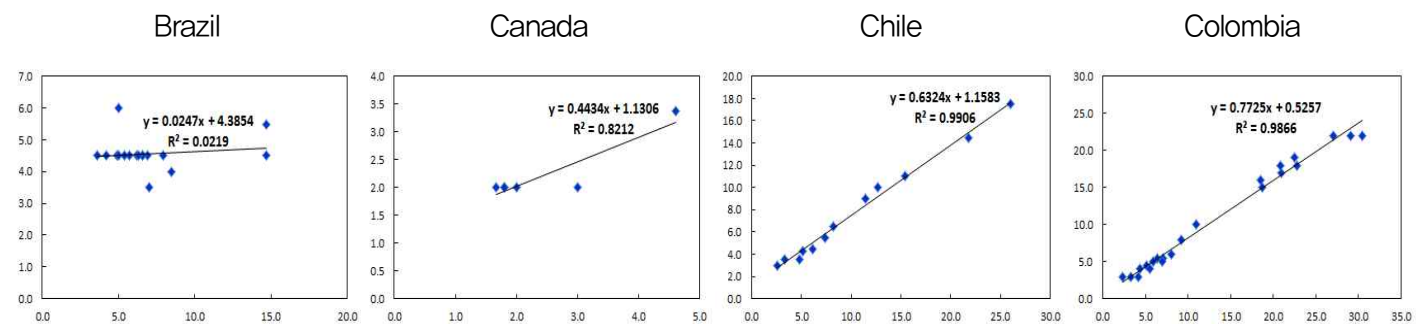

Czech Republic

Ghana

Guatemala

Hungary
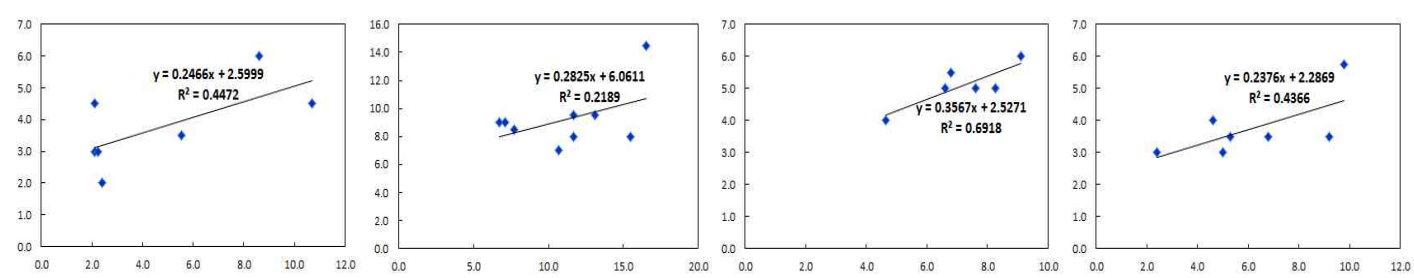

Indonesia

Israel

Korea

Mexico
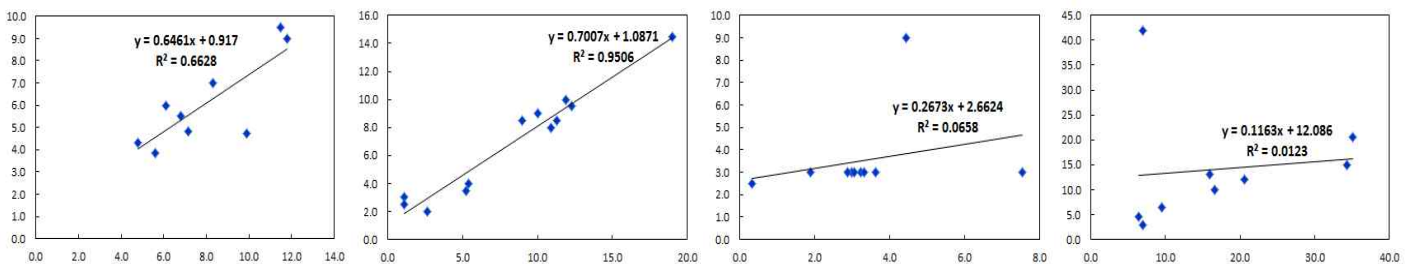

New Zealand

Peru

Philippines

Poland
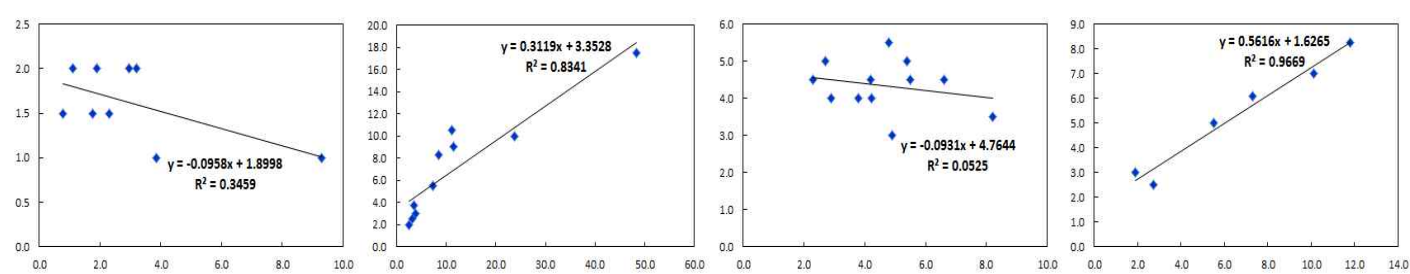

Romania

Thailand
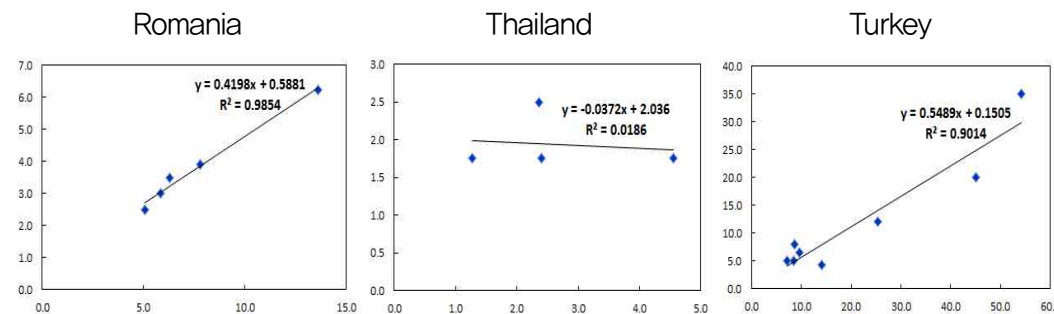

Note: 1) The horizontal axis indicates the average rate of inflation of previous inflation target years and the vertical axis indicates inflation target. 
Table 1: Granger Causality Test Results ${ }^{1)}$

\begin{tabular}{|c|c|c|c|c|c|c|}
\hline \multirow[b]{3}{*}{ Brazil } & \multicolumn{3}{|c|}{ Akaike Criterion } & \multicolumn{3}{|c|}{ Schwartz Criterion } \\
\hline & \multirow{2}{*}{$\begin{array}{r}\text { lag } \\
7\end{array}$} & \multicolumn{2}{|c|}{ F-value } & \multirow{2}{*}{$\begin{array}{l}\text { lag } \\
2\end{array}$} & \multicolumn{2}{|c|}{ F-value ${ }^{2)}$} \\
\hline & & 3.485 *** & {$[0.002]$} & & 0.596 & {$[0.552]$} \\
\hline Canada & 12 & $1.753 *$ & {$[0.056]$} & 1 & 2.468 & {$[0.117]$} \\
\hline Chile & 6 & $2.817^{* *}$ & {$[0.011]$} & 1 & $6.882 * * *$ & {$[0.009]$} \\
\hline Colombia & 6 & $8.386 * * *$ & {$[0.000]$} & 2 & $11.606^{* * *}$ & {$[0.000]$} \\
\hline Czech & 3 & 1.601 & {$[0.191]$} & 1 & 1.237 & {$[0.268]$} \\
\hline Ghana & 1 & 2.928 * & [0.090] & 1 & $2.928 *$ & {$[0.090]$} \\
\hline Guatemala & 5 & $5.124^{* * *}$ & {$[0.000]$} & 2 & $6.463^{* * *}$ & {$[0.002]$} \\
\hline Hungary & 2 & 0.560 & {$[0.572]$} & 1 & 1.013 & {$[0.316]$} \\
\hline Indonesia & 4 & $11.263^{* * *}$ & {$[0.000]$} & 1 & $7.934^{* * *}$ & {$[0.006]$} \\
\hline Israel & 7 & $4.289 * * *$ & {$[0.000]$} & 2 & $3.471^{* *}$ & {$[0.032]$} \\
\hline Korea & 0 & - & & 0 & - & \\
\hline Mexico & 12 & $11.276^{* * *}$ & {$[0.000]$} & 5 & 2.879 ** & {$[0.015]$} \\
\hline New Zealand & 4 & 0.125 & [0.973] & 1 & 0.048 & [0.827] \\
\hline Peru & 2 & 2.075 & {$[0.128]$} & 2 & 2.075 & {$[0.128]$} \\
\hline Philippines & 2 & $4.334^{* *}$ & {$[0.015]$} & 2 & $4.334^{* *}$ & {$[0.015]$} \\
\hline Poland & 2 & $3.545 * *$ & {$[0.031]$} & 2 & $3.545^{* *}$ & {$[0.031]$} \\
\hline Romania & 12 & $2.186 * *$ & {$[0.019]$} & 1 & 0.240 & {$[0.625]$} \\
\hline Turkey & 12 & $2.630^{* * *}$ & {$[0.004]$} & 1 & $14.940^{* * *}$ & {$[0.000]$} \\
\hline
\end{tabular}

Notes: 1) The null hypothesis is that an actual inflation does not Granger cause an inflation target.

2) The bold numbers are F-values and their corresponding p-values are in brackets. *, **, $* * *$ mean that the estimates are significant at the $10 \%, 5 \%$, and $1 \%$ significance levels respectively.

\section{Granger causality test}

Table 1 reports the results of the Granger causality test. For each country, we report two results; one is when the lag length is selected based on Akaike Criterion, and the other is when the lag length is selected based on Schwartz Criterion. The null hypothesis is that inflation rates do not Granger cause inflation targets. In many countries, past inflation rates help explain the 


\section{Table 2: Equation (1) Estimation Result}

\begin{tabular}{|c|c|c|c|c|c|c|c|c|c|}
\hline & \multicolumn{3}{|c|}{ Pooled OLS') } & \multicolumn{3}{|c|}{ Fixed Effect Model') } & \multicolumn{3}{|c|}{ Random Effect Model ${ }^{1)}$} \\
\hline & \multicolumn{3}{|c|}{$\pi_{-}$target } & \multicolumn{3}{|c|}{$\pi_{-}$target } & \multicolumn{3}{|c|}{$\pi_{-}$target } \\
\hline const & $\begin{array}{l}1.874^{* * *} \\
{[0.365]}\end{array}$ & $\begin{array}{l}2.099^{* * *} \\
{[0.393]}\end{array}$ & $\begin{array}{l}1.768^{* * *} \\
{[0.376]}\end{array}$ & $\begin{array}{l}2.382^{* * *} \\
{[0.394]}\end{array}$ & $\begin{array}{l}2.544^{* * *} \\
{[0.419]}\end{array}$ & $\begin{array}{l}2.275^{* * *} \\
{[0.405]}\end{array}$ & $\begin{array}{c}1.874^{* * *} \\
{[0.365]}\end{array}$ & $\begin{array}{l}2.131 * * * \\
{[0.442]}\end{array}$ & $\begin{array}{l}1.793^{* * *} \\
{[0.389]}\end{array}$ \\
\hline$\pi_{-}$past $1^{2)}$ & $\begin{array}{l}0.538^{* * *} \\
{[0.030]}\end{array}$ & & & $\begin{array}{l}0.479^{* * * *} \\
{[0.035]}\end{array}$ & & & $\begin{array}{l}0.538^{* * *} \\
{[0.030]}\end{array}$ & & \\
\hline$\pi_{-}$past $2^{2)}$ & & $\begin{array}{l}0.479 * * * \\
{[0.030]}\end{array}$ & & & $\begin{array}{l}0.431^{* * *} \\
{[0.035]}\end{array}$ & & & $\begin{array}{l}0.463^{* * *} \\
{[0.031]}\end{array}$ & \\
\hline$\pi_{-}$past $3^{2)}$ & & & $\begin{array}{l}0.539^{* * * *} \\
{[0.031]}\end{array}$ & & & $\begin{array}{l}0.482^{* * *} \\
{[0.036]}\end{array}$ & & & $\begin{array}{l}0.532^{* * *} \\
{[0.031]}\end{array}$ \\
\hline Observations & 180 & 180 & 180 & 180 & 180 & 180 & 180 & 180 & 180 \\
\hline $\mathrm{R}^{2}$ & 0.642 & 0.584 & 0.633 & 0.536 & 0.482 & 0.529 & & & \\
\hline
\end{tabular}

Notes: 1) Standard errors are in brackets. $*, * *, * * *$ mean that the estimates are significant at the $10 \%, 5 \%$, and $1 \%$ significance levels respectively.

2) $\pi_{-}$past 1 is the inflation rate of the previous one year, $\pi_{-}$past 2 is the average inflation rate of the past two years, and $\pi_{-}$past 3 is the average inflation rate for the past target horizon.

movement of inflation targets. In 14 out of total 18 countries, the null hypothesis is rejected at least in one case at the $10 \%$ significance level. In eight countries (Chile, Colombia, Guatemala, Indonesia, Israel, the Philippines, Poland and Turkey), the null hypothesis is rejected in both cases at the $5 \%$ significance level. The results suggest that past inflation rates are likely to influence inflation targets in many countries.

\section{Panel regression}

Table 2 shows the panel regression estimates for equation (1) by pooled OLS, the fixed effect model, and the random effect model. The estimates for the coefficient of the past inflation rate are significantly different from zero and positive. This result supports the idea that the past inflation performance affects the inflation target of the next period. The size of estimated coefficients ranges from 0.43 to 0.54 . In all cases, the coefficient is significant at the $1 \%$ significance level. 


\section{Table 3: Equation (2) Estimation Result}

\begin{tabular}{|c|c|c|c|c|c|c|c|c|c|}
\hline & \multicolumn{3}{|c|}{ Pooled OLS ${ }^{1)}$} & \multicolumn{3}{|c|}{ Fixed Effect Model' } & \multicolumn{3}{|c|}{ Random Effect Model ${ }^{1)}$} \\
\hline & \multicolumn{3}{|c|}{$\pi_{-}$target } & \multicolumn{3}{|c|}{$\pi_{-}$target } & \multicolumn{3}{|c|}{$\pi_{-}$target } \\
\hline const & $\begin{array}{l}1.177^{* * *} \\
{[0.200]}\end{array}$ & $\begin{array}{l}1.131^{* * *} \\
{[0.209]}\end{array}$ & $\begin{array}{l}1.125^{* * *} \\
{[0.204]}\end{array}$ & $\begin{array}{l}1.360^{* * *} \\
{[0.208]}\end{array}$ & $\begin{array}{l}1.269 * * * \\
{[0.218]}\end{array}$ & $\begin{array}{l}1.282^{* * *} \\
{[0.211]}\end{array}$ & $\begin{array}{l}1.175^{* * *} \\
{[0.238]}\end{array}$ & $\begin{array}{l}1.103^{* * *} \\
{[0.238]}\end{array}$ & $\begin{array}{l}1.103^{* * *} \\
{[0.240]}\end{array}$ \\
\hline$\pi_{-}$past $_{-1}$ & $\begin{array}{l}0.375^{* * *} \\
{[0.055]}\end{array}$ & $\begin{array}{l}0.477^{* * *} \\
{[0.050]}\end{array}$ & $\begin{array}{l}0.392^{* * *} \\
{[0.057]}\end{array}$ & $\begin{array}{l}0.318^{* * *} \\
{[0.053]}\end{array}$ & $\begin{array}{l}0.411^{* * *} \\
{[0.047]}\end{array}$ & $\begin{array}{l}0.315^{* * *} \\
{[0.055]}\end{array}$ & $\begin{array}{l}0.338^{* * *} \\
{[0.052]}\end{array}$ & $\begin{array}{l}0.440^{* * *} \\
{[0.047]}\end{array}$ & $\begin{array}{l}0.343^{* * *} \\
{[0.054]}\end{array}$ \\
\hline$\pi_{-}$past $1^{2)}$ & $\begin{array}{l}0.271^{* * *} \\
{[0.046]}\end{array}$ & & & $\begin{array}{l}0.297^{* * *} \\
{[0.043]}\end{array}$ & & & $\begin{array}{l}0.287^{* * *} \\
{[0.043]}\end{array}$ & & \\
\hline$\pi \_p a s t 2^{2)}$ & & $\begin{array}{l}0.174^{* * *} \\
{[0.038]}\end{array}$ & & & $\begin{array}{l}0.212^{* * *} \\
{[0.036]}\end{array}$ & & & $\begin{array}{l}0.193^{* * *} \\
{[0.036]}\end{array}$ & \\
\hline$\pi \_p a s t 3^{2)}$ & & & $\begin{array}{l}0.258^{* * *} \\
{[0.048]}\end{array}$ & & & $\begin{array}{l}0.304^{* * *} \\
{[0.045]}\end{array}$ & & & $\begin{array}{l}0.285^{* * *} \\
{[0.045]}\end{array}$ \\
\hline observations & 180 & 180 & 180 & 180 & 180 & 180 & 180 & 180 & 180 \\
\hline $\mathrm{R}^{2}$ & 0.862 & 0.851 & 0.858 & 0.836 & 0.824 & 0.834 & & & \\
\hline $\begin{aligned} & \text { Notes: 1) St } \\
& \text { th } \\
& \text { 2) } \pi_{-}\end{aligned}$ & $\begin{array}{l}\text { andard err } \\
\text { past } 1 \text { is th }\end{array}$ & $\begin{array}{l}\text { rors are it } \\
\% \text {, and } 1 \% \\
\text { he inflatic }\end{array}$ & $\begin{array}{l}\text { in bracke } \\
\% \text { signific } \\
\text { ion rate }\end{array}$ & $\begin{array}{l}\text { ts. }{ }^{*}, * * \\
\text { ance level } \\
\text { f the pre }\end{array}$ & $\begin{array}{l}\text { *** mear } \\
\text { ls respecti } \\
\text { evious one }\end{array}$ & $\begin{array}{l}\text { that the } \\
\text { ely. } \\
\text { year, } \pi_{-} p\end{array}$ & past 2 is th & $\begin{array}{l}\text { es are sig } \\
\text { he averag }\end{array}$ & nificant at \\
\hline
\end{tabular}

Table 3 shows the results of the estimation of equation (2) that additionally includes the inflation target of the previous period as an independent variable. Even after we control for the inflation target of the previous period, the estimates for the coefficient of the past inflation rate are significantly different from zero and positive at the $1 \%$ significance level in all cases. However, the size of the estimates shrinks to $0.17 \sim 0.30$. This results imply that the past inflation performance affects inflation targets even after controlling for past inflation targets.

As explained in Section 2, equation (3) models the behavior of central banks in the following way. A central bank may adjust its current inflation target aside from the past as it fails to match an actual inflation rate with the target rate in the past. We report the results in Table 4. Although the estimates are not significant in pooled OLS, the estimates are positive and significant in all cases of the fixed effect model as well as in most cases of the random effect model. The size of the estimates is in the range of 0.03 to 0.22 . These results are broadly consistent with the idea that when an inflation rate deviates from a 
Table 4: Equation (3) Estimation Result

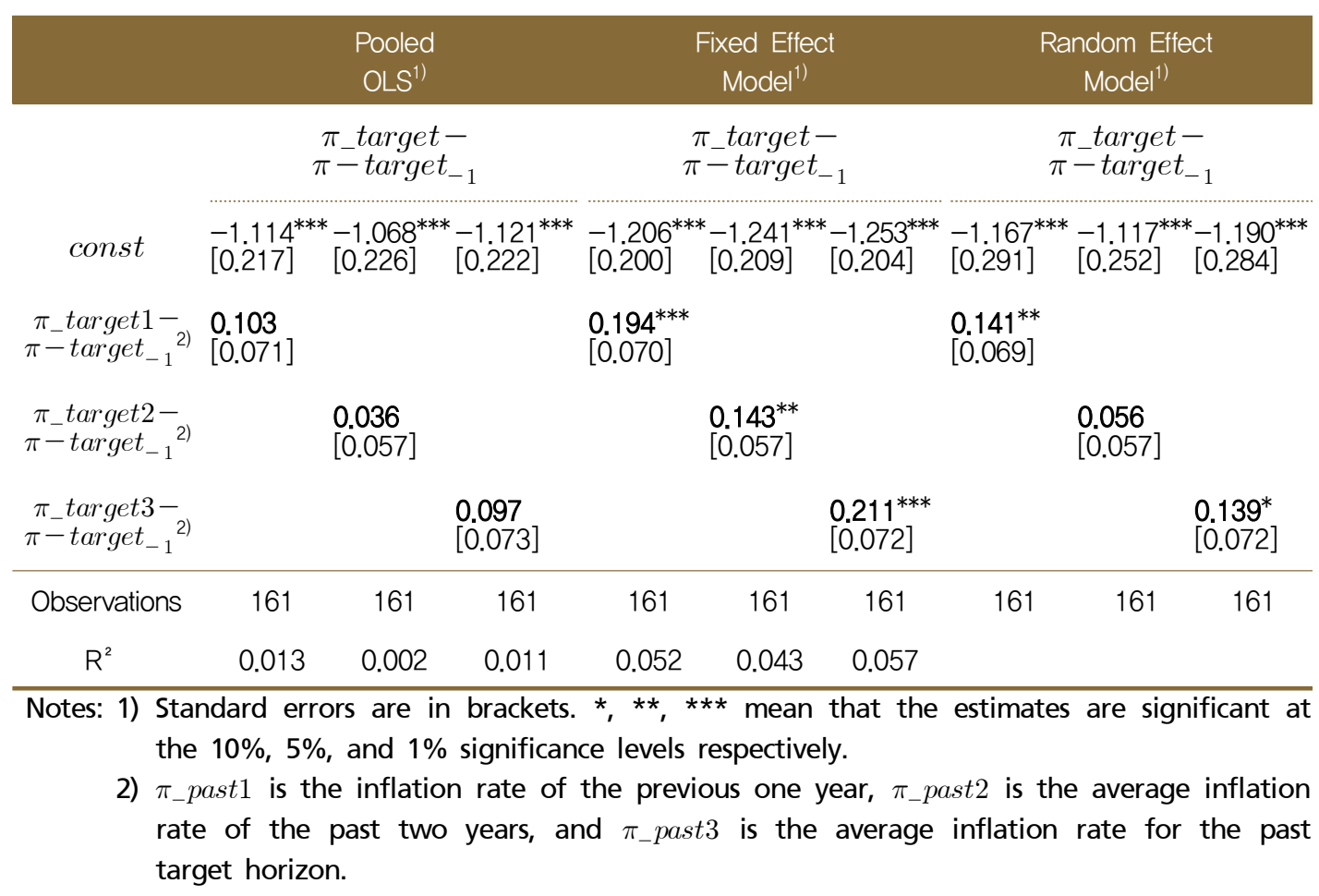

target, central banks tend to adjust the target of the next period in a way of reducing the deviation from the inflation rate and the target.

\section{Extended Experiments}

\section{Robustness}

In this section, we examined the robustness of the results by extending the model in various directions.

First, we restrict the sample period to the explicit inflation targeting period only, since the behavior of central banks during the implicit inflation targeting period may be different from that during the explicit inflation targeting period. As mentioned in Section 2, some countries like Chile, Colombia, Indonesia, and Peru operated the implicit inflation targeting period before explicitly adopting 
Table 5: Explicit Inflation Targeting Period (Equation (1))

\begin{tabular}{|c|c|c|c|c|c|c|c|c|c|}
\hline & \multicolumn{3}{|c|}{ Pooled OLS'1) } & \multicolumn{3}{|c|}{ Fixed Effect Model' } & \multicolumn{3}{|c|}{ Random Effect Model' } \\
\hline & & $\pi_{-}$targe & & & $\pi_{-}$targe & & & $\pi_{-} \_$target & \\
\hline const & $\begin{array}{l}1.454^{* * *} \\
{[0.234]}\end{array}$ & $\begin{array}{l}0.990^{* * *} \\
{[0.235]}\end{array}$ & $\begin{array}{l}1.377^{* * *} \\
{[0.259]}\end{array}$ & $\begin{array}{l}2.056^{* * *} \\
{[0.252]}\end{array}$ & $\begin{array}{l}1.563^{* * *} \\
{[0.261]}\end{array}$ & $\begin{array}{l}2.003^{* * *} \\
{[0.265]}\end{array}$ & $\begin{array}{l}1.622^{* * *} \\
{[0.256]}\end{array}$ & $\begin{array}{l}1.171^{* * *} \\
{[0.266]}\end{array}$ & $\begin{array}{l}1.635^{* * *} \\
{[0.311]}\end{array}$ \\
\hline$\pi_{-}$past $1^{2)}$ & $\begin{array}{l}0.539^{* * *} \\
{[0.033]}\end{array}$ & & & $\begin{array}{l}0.438^{* * *} \\
{[0.038]}\end{array}$ & & & $\begin{array}{l}0.502^{* * *} \\
{[0.034]}\end{array}$ & & \\
\hline$\pi \_$past $2^{2)}$ & & $\begin{array}{l}0.588^{* * *} \\
{[0.033]}\end{array}$ & & & $\begin{array}{l}0.496^{* * *} \\
{[0.038]}\end{array}$ & & & $\begin{array}{l}0.546^{* * *} \\
{[0.034]}\end{array}$ & \\
\hline$\pi \_p a s t 3^{2)}$ & & & $\begin{array}{l}0.532^{* * *} \\
{[0.036]}\end{array}$ & & & $\begin{array}{l}0.431 * * * \\
{[0.039]}\end{array}$ & & & $\begin{array}{l}0.466^{* * *} \\
{[0.036]}\end{array}$ \\
\hline Observations & 140 & 140 & 140 & 140 & 140 & 140 & 140 & 140 & 140 \\
\hline $\mathrm{R}^{2}$ & 0.658 & 0.703 & 0.615 & 0.526 & 0.582 & 0.506 & & & \\
\hline
\end{tabular}

Notes: 1) Standard errors are in brackets. ${ }^{*}, * *, * * *$ mean that the estimates are significant at the $10 \%, 5 \%$, and $1 \%$ significance levels respectively.

2) $\pi_{-}$past 1 is the inflation rate of the previous one year, $\pi_{-}$past 2 is the average inflation rate of the past two years, and $\pi_{-}$past 3 is the average inflation rate for the past target horizon.

inflation targeting. They assessed that they had weak macroeconomic preconditions required for the success of inflation targeting. Such conditions are, for instance, central bank independence, technical infrastructure including the capability to forecast major economic variables, well-functioning price system, and sound financial markets including banking and capital markets. The estimation results are displayed in Tables 5 and 6 . The results are qualitatively similar to the baseline case in which the implicit inflation targeting period is included in the sample. The inflation target still responds significantly to the past inflation. In both equation (1) and equation (2), the estimates of coefficient of the past inflation rate is significantly different from zero at the $1 \%$ significance level regardless of the estimation method. Also, the size of the estimates, which is between $0.431 \sim 0.588$ in equation (1) and 0.240 0.344 in equation (2), is similar to that of the whole inflation targeting period. 
Table 6: Explicit Inflation Targeting Period (Equation (2))

\begin{tabular}{|c|c|c|c|c|c|c|c|c|c|}
\hline & \multicolumn{3}{|c|}{ Pooled OLS1) } & \multicolumn{3}{|c|}{ Fixed Effect Model1) } & \multicolumn{3}{|c|}{ Random Effect Model1) } \\
\hline & \multicolumn{3}{|c|}{$\pi_{\text {_target }}$} & \multicolumn{3}{|c|}{$\pi_{-}$target } & \multicolumn{3}{|c|}{$\pi_{-}$target } \\
\hline const & $\begin{array}{l}0.585^{* * *} \\
{[0.203]}\end{array}$ & $\begin{array}{l}0.584^{* * *} \\
{[0.211]}\end{array}$ & $\begin{array}{l}0.544^{* *} \\
{[0.213]}\end{array}$ & $\begin{array}{l}1.258^{* * *} \\
{[0.263]}\end{array}$ & $\begin{array}{l}1.309^{* * *} \\
{[0.262]}\end{array}$ & $\begin{array}{l}1.263^{* * *} \\
{[0.269]}\end{array}$ & $\begin{array}{l}0.585^{* * *} \\
{[0.203]}\end{array}$ & $\begin{array}{l}0.584^{* * *} \\
{[0.211]}\end{array}$ & $\begin{array}{l}0.544^{* *} \\
{[0.213]}\end{array}$ \\
\hline$\pi_{-}$target $t_{-1}$ & $\begin{array}{l}0.492^{* * *} \\
{[0.052]}\end{array}$ & $\begin{array}{l}0.404^{* * *} \\
{[0.071]}\end{array}$ & $\begin{array}{l}0.512^{* * *} \\
{[0.055]}\end{array}$ & $\begin{array}{l}0.371^{* * *} \\
{[0.059]}\end{array}$ & $\begin{array}{l}0.229^{* * *} \\
{[0.078]}\end{array}$ & $\begin{array}{l}0.363^{* * *} \\
{[0.063]}\end{array}$ & $\begin{array}{l}0.492^{* * *} \\
{[0.052]}\end{array}$ & $\begin{array}{l}0.404^{* * *} \\
{[0.071]}\end{array}$ & $\begin{array}{l}0.512^{* * *} \\
{[0.055]}\end{array}$ \\
\hline$\pi \_$target $1^{2)}$ & $\begin{array}{l}0.258^{* * *} \\
{[0.039]}\end{array}$ & & & $\begin{array}{l}0.245^{* * *} \\
{[0.042]}\end{array}$ & & & $\begin{array}{l}0.258^{* * *} \\
{[0.039]}\end{array}$ & & \\
\hline$\pi_{-}$target $2^{2)}$ & & $\begin{array}{l}0.320^{* * *} \\
{[0.056]}\end{array}$ & & & $\begin{array}{l}0.344^{* * *} \\
{[0.060]}\end{array}$ & & & $\begin{array}{l}0.320^{* * *} \\
{[0.056]}\end{array}$ & \\
\hline$\pi_{-}$target $3^{2)}$ & & & $\begin{array}{l}0.240^{* * *} \\
{[0.042]}\end{array}$ & & & $\begin{array}{l}0.244^{* * *} \\
{[0.046]}\end{array}$ & & & $\begin{array}{l}0.240^{* * *} \\
{[0.042]}\end{array}$ \\
\hline Observations & 127 & 127 & 127 & 127 & 127 & 127 & 127 & 127 & 127 \\
\hline $\mathrm{R}^{2}$ & 0.799 & 0.783 & 0.783 & 0.630 & 0.627 & 0.614 & & & \\
\hline
\end{tabular}

Notes: 1) Standard errors are in brackets. ${ }^{*}, * *, * * *$ mean that the estimates are significant at the $10 \%, 5 \%$, and $1 \%$ significance levels respectively.

2) $\pi_{-}$past 1 is the inflation rate of the previous one year, $\pi_{-}$past 2 is the average inflation rate of the past two years, and $\pi_{-}$past 3 is the average inflation rate for the past target horizon.

Up to now, we analyze the effects of inflation rates on inflation targets. However, an inflation target may also affect an actual inflation rate. To control for such reverse causality, the system estimation is conducted by considering the following equation additionally.

$$
\pi_{-} \text {current }_{i t}=\delta_{0}+\delta_{1} \pi_{-} \text {target }_{i t}+\delta_{2} \pi_{-} \text {past }_{i t}+\varepsilon_{i t}
$$

The system of equations (2) and (4) is estimated by using three stage least squares (3SLS) method. Table 7 reports the results. 
Table 7: System Estimation Result (Equations (2) and (4))

\begin{tabular}{|c|c|c|c|c|c|c|}
\hline & \multicolumn{3}{|c|}{ Pooled OLS ${ }^{1 / 2)}$} & \multicolumn{3}{|c|}{ Fixed Effect Model ${ }^{1 / 2)}$} \\
\hline (Equation (2)) & \multicolumn{3}{|c|}{$\pi_{-}$target } & \multicolumn{3}{|c|}{$\pi_{-}$target } \\
\hline const & $\begin{array}{l}1.173^{* * *} \\
{[0.199]}\end{array}$ & $\begin{array}{l}1.172^{* * *} \\
{[0.210]}\end{array}$ & $\begin{array}{l}1.114^{* * *} \\
{[0.205]}\end{array}$ & $\begin{array}{l}-0.0113 \\
{[0.712]}\end{array}$ & $\begin{array}{l}0.917 \\
{[0.819]}\end{array}$ & $\begin{array}{l}0.837 \\
{[0.809]}\end{array}$ \\
\hline$\pi_{-}$target $t_{-1}$ & $\begin{array}{l}0.353^{* * *} \\
{[0.111]}\end{array}$ & $\begin{array}{l}0.558^{* * *} \\
{[0.060]}\end{array}$ & $\begin{array}{l}0.362^{* * *} \\
{[0.108]}\end{array}$ & $\begin{array}{l}0.207^{* *} \\
{[0.100]}\end{array}$ & $\begin{array}{l}0.458^{* * *} \\
{[0.052]}\end{array}$ & $\begin{array}{l}0.190^{*} \\
{[0.099]}\end{array}$ \\
\hline$\pi_{-}$target $1^{3)}$ & $\begin{array}{l}0.290^{* * *} \\
{[0.097]}\end{array}$ & & & $\begin{array}{l}0.399^{* * *} \\
{[0.089]}\end{array}$ & & \\
\hline$\pi_{-}$target $2^{3)}$ & & $\begin{array}{l}0.103^{* *} \\
{[0.048]}\end{array}$ & & & $\begin{array}{l}0.168^{* * *} \\
{[0.042]}\end{array}$ & \\
\hline$\pi \_$target $3^{3)}$ & & & $\begin{array}{l}0.285^{* * *} \\
{[0.096]}\end{array}$ & & & $\begin{array}{l}0.421^{* * *} \\
{[0.090]}\end{array}$ \\
\hline Observations & 161 & 161 & 161 & 161 & 161 & 161 \\
\hline $\mathrm{R}^{2}$ & 0.862 & 0.847 & 0.857 & 0.898 & 0.894 & 0.897 \\
\hline (Equation (4)) & \multicolumn{3}{|c|}{$\pi_{\text {_current }}$} & \multicolumn{3}{|c|}{$\pi \_$current } \\
\hline const & $\begin{array}{l}-0.0446 \\
{[0.308]}\end{array}$ & $\begin{array}{l}-0.118 \\
{[0.259]}\end{array}$ & $\begin{array}{l}0.0856 \\
{[0.295]}\end{array}$ & $\begin{array}{l}0.539 \\
{[1.196]}\end{array}$ & $\begin{array}{l}-0.292 \\
{[1.005]}\end{array}$ & $\begin{array}{l}-0.101 \\
{[1.293]}\end{array}$ \\
\hline$\pi_{-}$target & $\begin{array}{l}0.823^{* * *} \\
{[0.055]}\end{array}$ & $\begin{array}{l}0.602^{* * *} \\
{[0.043]}\end{array}$ & $\begin{array}{l}0.811^{* * *} \\
{[0.052]}\end{array}$ & $\begin{array}{l}0.819^{* * *} \\
{[0.058]}\end{array}$ & $\begin{array}{l}0.579^{* * *} \\
{[0.046]}\end{array}$ & $\begin{array}{l}0.808^{* * *} \\
{[0.054]}\end{array}$ \\
\hline$\pi_{-}$past $1^{3)}$ & $\begin{array}{l}0.248^{* * *} \\
{[0.037]}\end{array}$ & & & $\begin{array}{l}0.247^{* * *} \\
{[0.037]}\end{array}$ & & \\
\hline$\pi \_$past $2^{3)}$ & & $\begin{array}{l}0.455^{* * *} \\
{[0.027]}\end{array}$ & & & $\begin{array}{l}0.478^{* * *} \\
{[0.028]}\end{array}$ & \\
\hline$\pi_{-}$past $3^{3)}$ & & & $\begin{array}{l}0.254^{* * *} \\
{[0.035]}\end{array}$ & & & $\begin{array}{l}0.249^{* * *} \\
{[0.036]}\end{array}$ \\
\hline Observations & 161 & 161 & 161 & 161 & 161 & 161 \\
\hline$R^{2}$ & 0.877 & 0.924 & 0.885 & 0.891 & 0.932 & 0.899 \\
\hline
\end{tabular}

Notes: 1) Standard errors are in brackets. ${ }^{*}, * *, * * *$ mean that the estimates are significant at the $10 \%, 5 \%$, and $1 \%$ significance levels respectively.

2) Models are estimated using three stage least squares(3SLS) method.

3) $\pi_{-}$past 1 is the inflation rate of the previous one year, $\pi_{-}$past 2 is the average inflation rate of the past two years, and $\pi_{-}$past 3 is the average inflation rate for the past target horizon.

The result still shows that the inflation performance affects next period's inflation target. Interestingly, by considering the reverse causality from inflation target to current inflation, the size of the estimated coefficient on the past inflation rate even increases, except for the case in which the average of inflation rates in previous two years is used. The estimates of past inflation rates by pooled OLS increases from 0.271 to 0.290 when the one-year inflation rate is used. It increases from 0.259 to 0.285 when the average of inflation rates of the previous inflation targeting period is used. The estimates of past inflation rates by the fixed effect model increase from 0.297 to 0.399 
and 0.304 to 0.421 , respectively.

Finally, equation (2) is a variant of dynamic panel model, but we decide not to report the result using the GMM method (that resolves the problem of correlation between the dependent variable and the error term) for the following reasons. First, our sample observations are different from usual calendar years, but depend on a varying inflation targeting horizon. Second, the number of observations is small. We still experiment with estimating the model using the GMM method. The results are explained in Tables A2, A3, and A4 in the Appendix. The results are qualitatively similar.

\section{Central bank performance}

In this paper, we found a tendency that central banks respond to past inflation rates when they set their inflation target, that is, the endogeneity of inflation target. Then why does such an endogeneity exist?6) In the introduction, we discuss a possibility that a central bank sets its inflation target by tracking past inflation rates to maintain its reputation under the pressure on hitting the target ranges. If that is the case, we may observe stronger endogeneity among central banks that have weaker reputation. That is, when the performance of a central bank regarding inflation targeting is relatively weak, the central bank has some incentive to raise its reputation by changing the target and reducing the gap between the inflation target and an actual inflation rate. In this section, we examine the relation between central bank's performance and the degree of endogeneity of inflation target.

We use the following central bank performance indicator in the analysis:

$$
\text { performance indicator }=\left(\pi_{t}-\bar{\pi}_{t}\right)^{2}
$$

where $\pi_{t}$ and $\bar{\pi}_{t}$ are an actual inflation rate and inflation target, respectively. In

6) With respect to the upward adjustment of inflation target in 2005, Bank Indonesia insisted that the premises at the time of setting the inflation targets did not coincide with the actual condition and the inflation targets had to be reevaluated (Bank Indonesia (2007)). However, there was a criticism that although Bank Indonesia officially committed to an inflation targeting framework, the Bank's actual decisions did not reflect this commitment (McLeod (2008)). 
equation (5), high (low) value of the indicator represents weak (strong) performance of a central bank that tries to keep the inflation rate near the target.

This performance indicator is closely related to the central bank credibility. The definition of the indicator is consistent with the common notion that "the credibility means that your pronouncements are believed" (Blinder (1998)). Recently, Bordo and Siklos (2014, 2015a, 2015b) express the credibility of a central bank as the squared differential between the observed inflation rate and central bank's target, similarly to equation (5). The difference is that Bordo and Siklos (2014, 2015a, 2015b) estimate 'implied inflation objective' from the monetary policy rule such as the Taylor Rule as a proxy for, but this paper uses the exact inflation target data that central banks actually announced.

We compute the average of the performance indicator after the adoption of inflation targeting using monthly inflation data of each country. Then, we classify 19 countries into two groups, based on the average values of the performance indicator. The high performance group includes Canada, Chile, Czech Republic, Israel, Korea, New Zealand, Peru, the Philippines, Poland, and Thailand, while the low performance group includes Brazil, Colombia, Ghana, Guatemala, Hungary, Indonesia, Mexico, Romania, and Turkey. Detailed information about the indicator values and classification is shown in Table A5 of the Appendix.

Tables 8 and 9 present the estimation results for equations (1) and (2), respectively, for each group. The results show that in both groups, past inflation rates have a positive effect on the inflation target of the next period. The estimated coefficient is larger in the low performance group than that in the high performance group in all cases. In addition, the estimated coefficients are significantly different from zero in all cases of the low performance group, but not in a few cases of high performance group. These results suggest that past inflation rates affect inflation targets more strongly in the low performance group than in the high performance group. In other words, we find stronger endogeneity of an inflation target in central banks with low reputation or weak performance. 
Table 8: The Role of Targeting Performance (Equation (1))

\begin{tabular}{|c|c|c|c|c|c|c|c|c|c|}
\hline & \multicolumn{3}{|c|}{ Pooled OLS ${ }^{1)}$} & \multicolumn{3}{|c|}{ Fixed Effect Model ${ }^{11}$} & \multicolumn{3}{|c|}{ Random Effect Model1) } \\
\hline & \multicolumn{3}{|c|}{$\pi_{-}$target } & \multicolumn{3}{|c|}{$\pi_{-}$target } & \multicolumn{3}{|c|}{$\pi_{-}$target } \\
\hline const & $\begin{array}{l}2.046^{* * *} \\
{[0.244]}\end{array}$ & $\begin{array}{l}2.342^{* * *} \\
{[0.280]}\end{array}$ & $\begin{array}{l}1.961^{* * *} \\
{[0.259]}\end{array}$ & $\begin{array}{l}2.326^{* * *} \\
{[0.241]}\end{array}$ & $\begin{array}{l}2.577^{* * *} \\
{[0.269]}\end{array}$ & $\begin{array}{l}2.258^{* * *} \\
{[0.248]}\end{array}$ & $\begin{array}{l}2.084^{* * *} \\
{[0.274]}\end{array}$ & $\begin{array}{l}2.346^{* * *} \\
{[0.365]}\end{array}$ & $\begin{array}{l}2.010^{* * *} \\
{[0.309]}\end{array}$ \\
\hline$\pi \_p a s t 1^{2)}$ & $\begin{array}{l}0.457^{* * *} \\
{[0.026]}\end{array}$ & & & $\begin{array}{l}0.411^{* * *} \\
{[0.028]}\end{array}$ & & & $\begin{array}{l}0.442^{* * *} \\
{[0.027]}\end{array}$ & & \\
\hline$\pi_{-}$past $2^{2)}$ & & $\begin{array}{l}0.361^{* * *} \\
{[0.026]}\end{array}$ & & & $\begin{array}{l}0.327^{* * *} \\
{[0.027]}\end{array}$ & & & $\begin{array}{l}0.342^{* * *} \\
{[0.026]}\end{array}$ & \\
\hline$\pi_{-}$past $3^{2)}$ & & & $\begin{array}{l}0.457^{* * *} \\
{[0.028]}\end{array}$ & & & $\begin{array}{l}0.410^{* * *} \\
{[0.029]}\end{array}$ & & & $\begin{array}{l}0.435^{* * *} \\
{[0.028]}\end{array}$ \\
\hline observations & 88 & 88 & 88 & 88 & 88 & 88 & 88 & 88 & 88 \\
\hline$R^{2}$ & 0.776 & 0.691 & 0.758 & 0.733 & 0.654 & 0.727 & & & \\
\hline
\end{tabular}

(Countries with low performance)

\begin{tabular}{|c|c|c|c|c|c|c|c|c|c|}
\hline & \multicolumn{3}{|c|}{ Pooled OLS ${ }^{1)}$} & \multicolumn{3}{|c|}{ Fixed Effect Model ${ }^{11}$} & \multicolumn{3}{|c|}{ Random Effect Model ${ }^{1)}$} \\
\hline & \multicolumn{3}{|c|}{$\pi \_$target } & \multicolumn{3}{|c|}{$\pi_{-}$target } & \multicolumn{3}{|c|}{$\pi_{-}$target } \\
\hline const & $\begin{array}{l}1.919^{* * *} \\
{[0.727]}\end{array}$ & $\begin{array}{l}2.007^{* * *} \\
{[0.758]}\end{array}$ & $\begin{array}{c}1.811^{* *} \\
{[0.744]}\end{array}$ & $\begin{array}{l}2.449^{* * *} \\
{[0.777]}\end{array}$ & $\begin{array}{l}2.312^{* * *} \\
{[0.829]}\end{array}$ & $\begin{array}{l}2.300^{* * *} \\
{[0.799]}\end{array}$ & $\begin{array}{c}1.955^{* *} \\
{[0.761]}\end{array}$ & $\begin{array}{l}2.000^{* *} \\
{[0.883]}\end{array}$ & $\begin{array}{l}1.852^{* *} \\
{[0.810]}\end{array}$ \\
\hline$\pi \_p a s t 1^{2)}$ & $\begin{array}{l}0.563^{* * *} \\
{[0.051]}\end{array}$ & & & $\begin{array}{l}0.515^{* * *} \\
{[0.057]}\end{array}$ & & & $\begin{array}{l}0.555^{* * *} \\
{[0.051]}\end{array}$ & & \\
\hline$\pi_{-}$past $2^{2)}$ & & $\begin{array}{l}0.535^{* * *} \\
{[0.051]}\end{array}$ & & & $\begin{array}{l}0.509^{* * *} \\
{[0.060]}\end{array}$ & & & $\begin{array}{l}0.523^{* * *} \\
{[0.053]}\end{array}$ & \\
\hline$\pi \_$past $3^{2)}$ & & & $\begin{array}{l}0.564^{* * *} \\
{[0.052]}\end{array}$ & & & $\begin{array}{l}0.521^{* * *} \\
{[0.058]}\end{array}$ & & & $\begin{array}{l}0.552^{* * *} \\
{[0.052]}\end{array}$ \\
\hline observations & 92 & 92 & 92 & 92 & 92 & 92 & 92 & 92 & 92 \\
\hline $\mathrm{R}^{2}$ & 0.579 & 0.548 & 0.571 & 0.498 & 0.469 & 0.492 & - & - & - \\
\hline
\end{tabular}

Notes: 1) Standard errors are in brackets. ${ }^{*}, * *, * * *$ mean that the estimates are significant at the $10 \%, 5 \%$, and $1 \%$ significance levels respectively.

2) $\pi_{-}$past 1 is the inflation rate of the previous one year, $\pi_{-}$past 2 is the average inflation rate of the past two years, and $\pi_{-}$past 3 is the average inflation rate for the past target horizon. 
Table 9: The Role of Targeting Performance (Equation (2))

(Countries with high performance)

\begin{tabular}{|c|c|c|c|c|c|c|c|c|c|}
\hline & \multicolumn{3}{|c|}{ Pooled OLS ${ }^{1)}$} & \multicolumn{3}{|c|}{ Fixed Effect Model ${ }^{11}$} & \multicolumn{3}{|c|}{ Random Effect Model ${ }^{1)}$} \\
\hline & \multicolumn{3}{|c|}{$\pi_{-}$target } & \multicolumn{3}{|c|}{$\pi \_$target } & \multicolumn{3}{|c|}{$\pi \_$target } \\
\hline const & $\begin{array}{l}0.839^{* * *} \\
{[0.208]}\end{array}$ & $\begin{array}{l}0.768^{* * *} \\
{[0.227]}\end{array}$ & $\begin{array}{l}0.795^{* * *} \\
{[0.205]}\end{array}$ & $\begin{array}{l}1.060^{* * *} \\
{[0.259]}\end{array}$ & $\begin{array}{c}1.041^{* * *} \\
{[0.288]}\end{array}$ & $\begin{array}{c}1.046^{* * *} \\
{[0.255]}\end{array}$ & $\begin{array}{l}0.839^{* * *} \\
{[0.208]}\end{array}$ & $\begin{array}{l}0.768^{* * *} \\
{[0.227]}\end{array}$ & $\begin{array}{l}0.795^{* * *} \\
{[0.205]}\end{array}$ \\
\hline$\pi_{-}$target $_{-1}$ & $\begin{array}{l}0.502^{* * *} \\
{[0.080]}\end{array}$ & $\begin{array}{l}0.648^{* * *} \\
{[0.089]}\end{array}$ & $\begin{array}{l}0.498^{* * *} \\
{[0.081]}\end{array}$ & $\begin{array}{l}0.455^{* * *} \\
{[0.091]}\end{array}$ & $\begin{array}{l}0.552^{* * *} \\
{[0.106]}\end{array}$ & $\begin{array}{l}0.430 * * * \\
{[0.092]}\end{array}$ & $\begin{array}{l}0.502^{* * *} \\
{[0.080]}\end{array}$ & $\begin{array}{l}0.648^{* * *} \\
{[0.089]}\end{array}$ & $\begin{array}{l}0.498^{* * *} \\
{[0.081]}\end{array}$ \\
\hline$\pi \_p a s t 1^{2)}$ & $\begin{array}{l}0.187^{* * *} \\
{[0.064]}\end{array}$ & & & $\begin{array}{l}0.191^{* * *} \\
{[0.067]}\end{array}$ & & & $\begin{array}{l}0.187^{* * *} \\
{[0.064]}\end{array}$ & & \\
\hline$\pi \_p a s t 2^{2)}$ & & $\begin{array}{l}0.049 \\
{[0.057]}\end{array}$ & & & $\begin{array}{l}0.086 \\
{[0.063]}\end{array}$ & & & $\begin{array}{l}0.049 \\
{[0.057]}\end{array}$ & \\
\hline$\pi_{-}$past $3^{2)}$ & & & $\begin{array}{l}0.194^{* * *} \\
{[0.066]}\end{array}$ & & & $\begin{array}{l}0.213^{* * *} \\
{[0.069]}\end{array}$ & & & $\begin{array}{l}0.194^{* * *} \\
{[0.066]}\end{array}$ \\
\hline observations & 78 & 78 & 78 & 78 & 78 & 78 & 78 & 78 & 78 \\
\hline $\mathrm{R}^{2}$ & 0.873 & 0.860 & 0.873 & 0.800 & 0.782 & 0.804 & & & \\
\hline
\end{tabular}

(Countries with low performance)

\begin{tabular}{|c|c|c|c|c|c|c|c|c|c|}
\hline & \multicolumn{3}{|c|}{ Pooled OLS ${ }^{1)}$} & \multicolumn{3}{|c|}{ Fixed Effect Model ${ }^{1)}$} & \multicolumn{3}{|c|}{ Random Effect Model ${ }^{1)}$} \\
\hline & \multicolumn{3}{|c|}{$\pi_{-}$target } & \multicolumn{3}{|c|}{$\pi_{-}$target } & \multicolumn{3}{|c|}{$\pi_{-}$target } \\
\hline const & $\begin{array}{l}1.418^{* * *} \\
{[0.369]}\end{array}$ & $\begin{array}{l}1.426 * * * \\
{[0.383]}\end{array}$ & $\begin{array}{l}1.388^{* * *} \\
{[0.382]}\end{array}$ & $\begin{array}{l}1.479^{* * *} \\
{[0.351]}\end{array}$ & $\begin{array}{l}1.320^{* * *} \\
{[0.369]}\end{array}$ & $\begin{array}{l}1.377^{* * *} \\
{[0.361]}\end{array}$ & $\begin{array}{l}1.235^{* * *} \\
{[0.464]}\end{array}$ & $\begin{array}{l}1.181^{* * *} \\
{[0.450]}\end{array}$ & $\begin{array}{l}1.208^{* * *} \\
{[0.426]}\end{array}$ \\
\hline$\pi_{-}$target $_{-1}$ & $\begin{array}{l}0.356^{* * *} \\
{[0.078]}\end{array}$ & $\begin{array}{l}0.448^{* * *} \\
{[0.067]}\end{array}$ & $\begin{array}{l}0.379^{* * *} \\
{[0.082]}\end{array}$ & $\begin{array}{l}0.286^{* * *} \\
{[0.071]}\end{array}$ & $\begin{array}{l}0.381^{* * *} \\
{[0.060]}\end{array}$ & $\begin{array}{l}0.288^{* * *} \\
{[0.074]}\end{array}$ & $\begin{array}{l}0.300^{* * *} \\
{[0.071]}\end{array}$ & $\begin{array}{l}0.404^{* * *} \\
{[0.061]}\end{array}$ & $\begin{array}{l}0.322^{* * *} \\
{[0.076]}\end{array}$ \\
\hline$\pi_{-}$past $1^{2)}$ & $\begin{array}{l}0.274^{* * *} \\
{[0.067]}\end{array}$ & & & $\begin{array}{l}0.325^{* * *} \\
{[0.059]}\end{array}$ & & & $\begin{array}{l}0.314^{* * *} \\
{[0.059]}\end{array}$ & & \\
\hline$\pi_{-}$past $2^{2)}$ & & $\begin{array}{l}0.189^{* * *} \\
{[0.056]}\end{array}$ & & & $\begin{array}{l}0.252^{* * *} \\
{[0.050]}\end{array}$ & & & $\begin{array}{l}0.226^{* * *} \\
{[0.050]}\end{array}$ & \\
\hline$\pi \_p a s t 3^{2)}$ & & & $\begin{array}{l}0.254^{* * *} \\
{[0.071]}\end{array}$ & & & $\begin{array}{l}0.329^{* * *} \\
{[0.062]}\end{array}$ & & & $\begin{array}{l}0.298^{* * *} \\
{[0.065]}\end{array}$ \\
\hline observations & 83 & 83 & 83 & 83 & 83 & 83 & 83 & 83 & 83 \\
\hline $\mathrm{R}^{2}$ & 0.839 & 0.830 & 0.832 & 0.847 & 0.840 & 0.843 & & & \\
\hline
\end{tabular}

Notes: 1) Standard errors are in brackets. ${ }^{*}, *, * * *$ mean that the estimates are significant at the $10 \%, 5 \%$, and $1 \%$ significance levels respectively.

2) $\pi_{-}$past 1 is the inflation rate of the previous one year, $\pi_{-}$past 2 is the average inflation rate of the past two years, and $\pi_{-}$past 3 is the average inflation rate for the past target horizon. 


\section{Conclusion}

This paper empirically investigates whether an inflation target responds to past inflation rates in 19 inflation targeting countries. The empirical results show that the inflation target of many central banks respond significantly and positively to past inflation rates. This result does not depend on the methods we adopt, that is, the Granger causality test, scatter plot, and panel regression. The results suggest that there exists the endogeneity in inflation targets. We also show that strong endogeneity is found in a central bank with low credibility or weak performance, which may suggest that such an endogeneity may come from the incentive for a central bank to raise its reputation to reduce the deviation of an actual inflation rate from the target.

The analysis of this paper implies that it is better not to aggravate the endogeneity problem. In order for inflation targets to act as nominal anchors for monetary policy seeking stable growth, the targets should be the appropriate rates reflecting the structure of economy, and also set at the level of which is in line with the medium-term inflation path.

Some future studies are worthwhile. First, it is important to further investigate why some central banks change inflation targets in response to past inflation rates. Second, it is worthwhile to analyze what is the consequence of this endogeneity of inflation targets, for example, how it affects the social welfare and the overall macroeconomic performance of the economy and whether it stabilize/destabilize inflation rates and output. 


\section{References}

Anderson, D., D. P. J. Botman, and B. Hunt (2014), “Is Japan's Population Aging Deflationary?" IMF Working Paper 14/139.

Ball, L. M., N. Sheridan (2005), "Does Inflation Targeting Matter?" In Bernanke, B. S., Woodford, M. (Eds.), The Inflation-targeting Debate, University of Chicago Press.

Ball, L. (2010), "The Performance of Alternative Monetary Regimes," The Handbook of Monetary Economics, Vol. 3, Chapter 23.

Bank Indonesia (2007), "Economic Report on Indonesia," Jakarta: Bank Indonesia.

Blinder, A. S. (1999), "Central Banking in Theory and Practice," MIT Press.

Bordo, M. D., P. L. Siklos (2014), "Central Bank Credibility, Reputation and Inflation Targeting in Historical Perspective,” NBER Working Paper No. 20693.

Bordo, M. D., P. L. Siklos (2015a), "Central Bank Credibility: An Historical and Quantitative Exploration,” NBER Working Paper No. 20824.

Bordo, M. D., P. L. Siklos (2015b), "Central Bank Credibility Before and After the Crisis," NBER Working Paper No. 21710.

Brito, R. D., B. Bystedt (2010), "Inflation Targeting in Emerging Economies: Panel Evidence," Journal of Development Economics, Vol. 91(2), pp. 198-210.

Cecchetti, S. G., M. Ehrmann (1999), "Does Inflation Targeting Increase Output Volatility? An International Comparison of Policymakers' Preferences and Outcomes," NBER Working Paper No. 7426.

Geraats, P. M. (2013), "The Effect of Inflation Targeting: A Mean-Reverting Mirage?" University of Cambridge Working Paper. 
Gertler, M. (2005), Comment on L. Ball and N. Sheridan, "Does Inflation Targeting Matter?" In The Inflation Targeting Debate, edited by B. S. Bernanke and M. Woodford, 276-81, University of Chicago Press for the NBER.

Cogley, T., G. E. Primiceri, and T. J. Sargent (2010), "Inflation-Gap Persistence in the U.S.?" American Economic Journal: Macroeconomics, Vol. 2(1) pp. 43-69.

Gonçalves, C. E. S., J. M. Salles (2008), "Inflation Targeting in Emerging Economies: What Do the Data Say?" Journal of Development Economics, Vol. 85(1-2), pp. 312-318.

Gonçalves, C. E. S., A. Carvalho (2009), "Inflation Targeting Matters: Evidence from OECD Economies' Sacrifice Ratios," Journal of Money, Credit and Banking, Vol. 41(1), pp. 233-243.

Hammond, G. (2012), "State of the Art of Inflation Targeting," Center for Central Bank Studies Handbook, No. 29, Bank of England.

Hu, Y. (2003), "Empirical Investigations of Inflation Targeting," IIE Working Paper Series No. 03-6. Institute for International Economics, Washington.

Lin, S., H. Ye (2007), "Does Inflation Targeting Make a Difference? Evaluating the Treatment Effect of Inflation Targeting in Seven Industrial Countries," Journal of Monetary Economics, Vol. 54(8), pp. 2521-2533.

Lin, S., H. Ye (2009), "Does Inflation Targeting Make a Difference in Developing Countries?" Journal of Monetary Economics, Vol. 89(1), pp. 118-123.

McLeod, R. H. (2008), "Survey of Recent Development," Bulletin of Indonesian Economic Studies, Vol. 44(2), pp. 183-208.

Mishkin, F. S., K. Schmidt-Hebbel (2002), "One Decade of Inflation Targeting in the World: What Do We Know and What Do We Need to Know?" In Inflation Targeting: Design, Performance, Challenges, edited by N. Loayza and R. Soto, Santiago: Central Bank of Chile. 
Mishkin, F. S., M. A. Savastano (2002), "Monetary Policy Strategies for Emerging Market Countries: Lessons from Latin America," Comparative Economic Studies, Vol. 44(2), pp. 45-82.

Mishkin, F. S. (2005), "The inflation Targeting Debate," John Kuszczak Memorial Lecture at the Bank of Canada's Annual Conference, Issues in Inflation Targeting, Ottawa, April 28-29, 2005.

Mishkin, F. S., K. Schmidt-Hebbel (2006), "Does Inflation Targeting Make a Difference?" Central Bank of Chile Working Papers No.404.

Neumann, M. J. M., J. Von Hagen (2002), "Does Inflation Targeting Matter?" Federal Reserve Bank of St. Louis Review, Vol. 84(4), pp. 127-148.

Svensson, Lars E. O. (2010), "Inflation Targeting," The Handbook of Monetary Economics, Vol. 3, Chapter 2, pp. 127-131.

Uhlig, H. (2004), "Comment" on "The Macroeconomic Effects of Inflation Targeting" by A. T. Levin, F. M. Natalucci, and J. M. Piger, in The Federal Reserve Bank of St. Louis Review, Vol. 86(4), pp. 51-80.

Vega, M., D. Winkelreid (2005), "Inflation Targeting and Inflation Behavior: A Successful Story," International Journal of Central Banking, Vol. 1(3), pp. 153-175.

Willard, L. B. (2012), "Does Inflation Targeting Matter? A Reassessment," Applied Economics, Vol. 44(17), pp. 2231-2244. 


\section{Appendix: Tables}

Table A1: Changes of Inflation Targets of Inflation Targeting Countries

\begin{tabular}{|c|c|c|c|c|c|c|c|c|c|c|c|c|c|c|c|c|c|}
\hline & Korea $^{2}$ & Thailand $^{22}$ & \begin{tabular}{|l|} 
Plilippines \\
\end{tabular} & Indonesia ${ }^{2}$ & Israel $^{3 / 3}$ & Poland $d^{4}$ & $\mathrm{Czech}^{5}$ & Chile & Brazil & Colombia & Peru & Hungary ${ }^{6}$ & Mexico & \begin{tabular}{|l|} 
Guatemala \\
\end{tabular} & Romania $^{7}$ & Turkey & Ghana \\
\hline 1990 & & \multirow{18}{*}{$\underline{0.0-3.596}$} & & & & & & & & 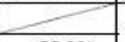 & & & & & & & \\
\hline 1991 & & & & & $140-15$ & & & $\frac{15.0-20096}{120-16096}$ & & $220 \%$ & & & & & & & \\
\hline 1092 & & & & & $10.0 \%$ & & & $\begin{array}{l}\frac{120-16096}{10.0-12.096} \\
\end{array}$ & & $\frac{220 \%}{220 \%}$ & & & & & & & \\
\hline 1094 & & & & & 8.096 & & & $20-11096$ & & $\frac{220 \%}{12.0 \%}$ & $150-200 \% 6$ & & & & & & \\
\hline 1995 & & & & & $60-11096$ & & & $9.0 \%$ & & $18.0 \%$ & $90-11096$ & & $42.0 \%$ & & & & \\
\hline 1996 & & & & & $30-100 \%$ & & & $6.5 \%$ & & $17.0 \%$ & $95-115 \%$ & & $20.5 \%$ & & & & \\
\hline 1997 & & & & & $7.0-10096$ & & & $5.5 \%$ & & $18.0 \%$ & $30-100 \%$ & & $15.0 \%$ & & & & \\
\hline 1996 & $2.0 \pm 1.096$ & & & & $7.0-10096$ & & $\underline{5.5-6.596}$ & $4.5 \%$ & & $16.0 \%$ & $7.5-9096$ & & $12.0 \%$ & & & & \\
\hline 1090 & $3.0 \pm 1.09 \%$ & & & & 4.096 & $8.0-8.596$ & $4.0-5.096$ & $43 \%$ & $8.0 \pm 2096$ & $15.0 \%$ & $50-60 \%$ & & $13.0 \%$ & & & & \\
\hline 2000 & $2.5 \pm 1.0 \%$ & & & $\underline{5.0-7.096}$ & $3.0-4096$ & $5.4-6.896$ & $\underline{3.5-5.596}$ & $3.5 \%$ & $6.0 \pm 2.0 \%$ & $10.0 \%$ & $35-40 \%$ & & $10.0 \%$ & & & & \\
\hline 2001 & $3.0 \pm 1.096$ & & & $4.0-6.096$ & $2.5-3.596$ & $6.0-8.096$ & $2.0-4.096$ & \multirow{6}{*}{$20-40 \%$} & $40 \pm 2.096$ & $8.0 \%$ & $25-35 \%$ & 7.096 & $6.5 \%$ & & & & \\
\hline 2000 & $\underline{3.0 \pm 1.0 \% 6}$ & & $45-5.596$ & $9.0-10.0 \%$ & $2.0-3.0 \% 6$ & $4.0-6.096$ & \multirow{4}{*}{$\begin{array}{c}3.0-5.0 \% 6 \\
\downarrow \\
20-4.0 \% 6 \\
\end{array}$} & & $3.5 \pm 2.096$ & 6.096 & \multirow{5}{*}{$2.5 \pm 1.086$} & $4.5 \%$ & $4.5 \%$ & & & $35.0 \%$ & N.A. \\
\hline 2008 & $3.0 \pm 1.096$ & & $45-5.5 \%$ & $2.0 \pm 1.096$ & \multirow{15}{*}{$1.0-3.096$} & $20-4.0 \%$ & & & $40 \pm 2596$ & $5.0-6.096$ & & $3.5 \%$ & \multirow{15}{*}{$3.0 \pm 1.096$} & & & $20.0 \%$ & N.A. \\
\hline 2004 & \multirow{3}{*}{$\underline{2.5-3.596}$} & & $40-5.096$ & $5.5 \pm 1.096$ & & \multirow{14}{*}{$2.5 \pm 1.096$} & & & $5.5 \pm 2.5 \%$ & $5.0-6.096$ & & $3.6 \%$ & & & & $120 \%$ & N.A. \\
\hline 2005 & & & $5.0-6.086$ & $6.0 \pm 1.096$ & & & & & $45 \pm 2.5 \%$ & $4.5 \sim 5.596$ & & 4096 & & $40-6.096$ & $7.5 \pm 1096$ & $8.0 \%$ & N.A. \\
\hline 2006 & & & $40 \sim 5.096$ & $8.0 \pm 1.096$ & & & \multirow{4}{*}{$3.0 \pm 1.096$} & & $45 \pm 20 \%$ & $4.0-5.096$ & & $3.5 \%$ & & $6.0 \pm 1.0 \%$ & $5.0 \pm 1096$ & 5.096 & N.A. \\
\hline 2007 & \multirow{3}{*}{$3.0 \pm 0.5 \%$} & & $40-5.096$ & $6.0 \pm 1.096$ & & & & \multirow{11}{*}{$3.0 \pm 1.096$} & $45 \pm 2096$ & $3.5 \sim 4.596$ & \multirow{11}{*}{$20 \pm 1.096$} & \multirow{8}{*}{$3.0 \%$} & & $5.0 \pm 10 \%$ & $40 \pm 1096$ & $40 \%$ & $7.0-9.096$ \\
\hline 2000 & & & $40 \pm 10 \%$ & $5.0 \pm 1.096$ & & & & & $45 \pm 2.0 \%$ & $3.5-4.5 \%$ & & & & $5.5 \pm 1.5 \%$ & $3.8=$ & $4.0 \%$ & $6.0-0.096$ \\
\hline 2000 & & $0.5 \sim 3.0 \%$ & $3.5 \pm 10 \%$ & $4.5 \pm 1.0 \%$ & & & & & $45 \pm 2096$ & $4.5 \sim 5.596$ & & & & & & & $12.5-165 \%$ \\
\hline 2010 & \multirow{3}{*}{$3.0 \pm 1.096$} & \multirow{5}{*}{$\underline{0.5-3.096}$} & $45 \pm 1.096$ & $5.0 \pm 1.0 \%$ & & & \multirow{8}{*}{$20 \pm 1.096$} & & $45 \pm 2096$ & $3.0 \pm 1.096$ & & & & $5.0 \pm 1.0 \%$ & $3.5 \pm 10 \%$ & 6.596 & $9.5 \pm 2.096$ \\
\hline 2011 & & & $40 \pm 1096$ & $5.0 \pm 1.0 \%$ & & & & & $45 \pm 2.096$ & $3.0 \pm 1.096$ & & & & $5.0 \pm 1.0 \%$ & $3.0 \pm 10 \%$ & & $9.0 \pm 2.096$ \\
\hline 2012 & & & & $4.5 \pm 1.0 \%$ & & & & & $45 \pm 20 \%$ & \multirow{6}{*}{$3.0 \pm 1.096$} & & & & $45 \pm 10 \%$ & $3.0 \pm 10 \%$ & \multirow{3}{*}{5.096} & $8.5 \pm 2.096$ \\
\hline 2013 & \multirow{3}{*}{$2.5 \sim 3.5 \%$} & & $40 \pm 1096$ & $4.5 \pm 1.096$ & & & & & $45 \pm 2096$ & & & & & \multirow{5}{*}{$40 \pm 10 \%$} & \multirow{5}{*}{$25 \pm 10 \%$} & & $9.0 \pm 2.0 \%$ \\
\hline 2014 & & & & $4.5 \pm 1.096$ & & & & & $45 \pm 2.096$ & & & & & & & & $9.5 \pm 2.096$ \\
\hline 2015 & & \multirow{3}{*}{$25 \pm 1.5 \%$} & $30 \pm 108$ & $4.0 \pm 1.0 \%$ & & & & & $45 \pm 2086$ & & & \multirow{3}{*}{$3.0 \pm 1.096$} & & & & \multirow{3}{*}{5.096} & $8.0 \pm 2.0 \%$ \\
\hline 2016 & & & & & & & & & $45 \pm 2.096$ & & & & & & & & \\
\hline 2017 & & & $3.0 \pm 1096$ & $4.0 \pm 1.096$ & & & & & $45 \pm 1.5 \%$ & & & & & & & & \\
\hline
\end{tabular}

Notes: 1) The shaded part means the year in which explicit targeting became official.

2) The underlined numbers mean core inflation.

3) Israel shifted to long term target regime in August 2000. From 2003, inflation target is set as 1 3\% for an indefinite period.

4) Poland shifted to continuous time inflation target from 2004.

5) Target index was net (core) inflation until 2001 and changed into headline inflation from 2002

6) From 2003, medium term target horizon was adopted.

7) From 2013, the phase of a flat multi-annual inflation target intermediate stage meant to ensure the transition towards the phase of long-term continuous inflation targeting. 
Table A1: Changes of Inflation Targets of Inflation Targeting Countries (continued)

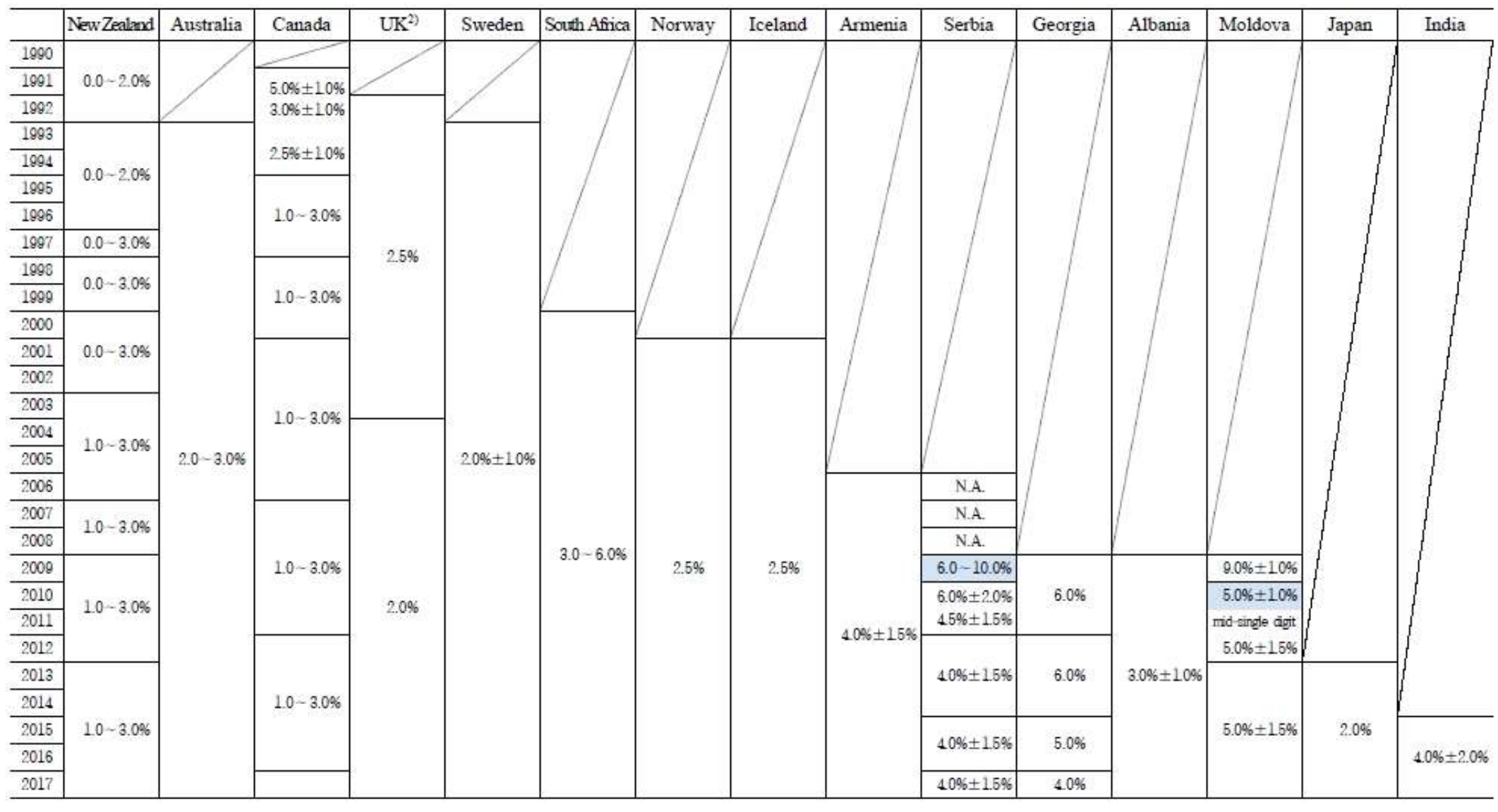

Notes: 1) The shaded part means the year in which explicit targeting became official. 2) Inflation target index was changed from RPIX into CPI from 2004.

Source: Central Banks, etc. 
Table A2: GMM Estimation Result (Equation (2))

\begin{tabular}{|c|c|c|c|c|c|c|c|c|c|c|c|c|}
\hline & \multicolumn{6}{|c|}{ First Difference GMM } & \multicolumn{6}{|c|}{ System GMM } \\
\hline & \multicolumn{3}{|c|}{ One Step GMM } & \multicolumn{3}{|c|}{ Two Step GMM3) } & \multicolumn{3}{|c|}{ One Step GMM } & \multicolumn{3}{|c|}{ Two Step GMM3) } \\
\hline & \multicolumn{3}{|c|}{$\pi_{-}$target } & \multicolumn{3}{|c|}{$\pi_{-}$target } & \multicolumn{3}{|c|}{$\pi_{-}$target } & \multicolumn{3}{|c|}{$\pi \_$target } \\
\hline const & $\begin{array}{c}1.519^{* * *} \\
{[0.175]}\end{array}$ & $\begin{array}{l}1.441^{* * * *} \\
{[0.188]}\end{array}$ & $\begin{array}{c}1.473^{* * *} \\
{[0.181]}\end{array}$ & $\begin{array}{c}1.438^{* * *} \\
{[0.470]}\end{array}$ & $\begin{array}{c}1.406^{* * *} \\
{[0.474]}\end{array}$ & $\begin{array}{c}1.459^{* * *} \\
{[0.510]}\end{array}$ & $\begin{array}{c}1.486^{* * *} \\
{[0.170]}\end{array}$ & $\begin{array}{c}1.459^{* * *} \\
{[0.178]}\end{array}$ & $\begin{array}{c}1.455^{* * *} \\
{[0.173]}\end{array}$ & $\begin{array}{c}1.418^{* * *} \\
{[0.522]}\end{array}$ & $\begin{array}{c}1.355^{* * *} \\
{[0.491]}\end{array}$ & $\begin{array}{c}1.425^{* * *} \\
{[0.463]}\end{array}$ \\
\hline$\pi_{-}$target$_{-1}$ & $\begin{array}{c}0.420 * * * \\
{[0.052]}\end{array}$ & $\begin{array}{l}0.465^{* * *} \\
{[0.048]}\end{array}$ & $\begin{array}{c}0.429^{* * * *} \\
{[0.055]}\end{array}$ & $\begin{array}{c}0.416^{* * *} \\
{[0.144]}\end{array}$ & $\begin{array}{l}0.463^{* * *} \\
{[0.0964]}\end{array}$ & $\begin{array}{l}0.428^{* *} \\
{[0.201]}\end{array}$ & $\begin{array}{c}0.460^{* * *} \\
{[0.049]}\end{array}$ & $\begin{array}{c}0.491^{* * *} \\
{[0.045]}\end{array}$ & $\begin{array}{c}0.451^{* * *} \\
{[0.052]}\end{array}$ & $\begin{array}{l}0.470^{* *} \\
{[0.189]}\end{array}$ & $\begin{array}{c}0.491^{* * *} \\
{[0.130]}\end{array}$ & $\begin{array}{c}0.451^{* * *} \\
{[0.138]}\end{array}$ \\
\hline$\pi \_p a s t 1^{2)}$ & $\begin{array}{c}0.188^{* * *} \\
{[0.042]}\end{array}$ & & & $\begin{array}{l}0.190^{* *} \\
{[0.090]}\end{array}$ & & & $\begin{array}{c}0.157^{* * *} \\
{[0.039]}\end{array}$ & & & $\begin{array}{c}0.149 \\
{[0.135]}\end{array}$ & & \\
\hline$\pi \_p a s t 2^{2)}$ & & $\begin{array}{c}0.147^{* * *} \\
{[0.037]}\end{array}$ & & & $\begin{array}{l}0.149^{* *} \\
{[0.071]}\end{array}$ & & & $\begin{array}{c}0.124^{* * *} \\
{[0.033]}\end{array}$ & & & $\begin{array}{c}0.127 \\
{[0.093]}\end{array}$ & \\
\hline$\pi \_$past $3^{2)}$ & & & $\begin{array}{c}0.183^{* * *} \\
{[0.045]}\end{array}$ & & & $\begin{array}{c}0.184 \\
{[0.203]}\end{array}$ & & & $\begin{array}{c}0.166^{* * *} \\
{[0.042]}\end{array}$ & & & $\begin{array}{c}0.168 \\
{[0.127]}\end{array}$ \\
\hline observations & 142 & 142 & 142 & 142 & 142 & 142 & 161 & 161 & 161 & 161 & 161 & 161 \\
\hline $\begin{array}{c}\text { number of } \\
\text { instrumental } \\
\text { variables }\end{array}$ & 62 & 62 & 62 & 62 & 62 & 62 & 79 & 79 & 79 & 79 & 79 & 79 \\
\hline
\end{tabular}

Notes: 1) Standard errors are in brackets. $*, * *, * *$ mean that the estimates are significant at the $10 \%, 5 \%$, and $1 \%$ significance levels respectively.

2) $\pi_{-}$past 1 is the inflation rate of the previous one year, $\pi_{-}$past 2 is the average inflation rate of the past two years, and $\pi_{-}$past 3 is the average inflation rate for the past target horizon.

3) Windmeijer (2005) bias-corrected robust standard errors are reported. 
Table A3: Explicit Inflation Targeting Period - GMM Estimation Result (Equation (2))

\begin{tabular}{|c|c|c|c|c|c|c|c|c|c|c|c|c|}
\hline & \multicolumn{6}{|c|}{ First Difference GMM } & \multicolumn{6}{|c|}{ System GMM } \\
\hline & \multicolumn{3}{|c|}{ One Step GMM } & \multicolumn{3}{|c|}{ Two Step GMM3) } & \multicolumn{3}{|c|}{ One Step GMM } & \multicolumn{3}{|c|}{ Two Step GMM3) } \\
\hline & \multicolumn{3}{|c|}{$\pi_{-}$target } & \multicolumn{3}{|c|}{$\pi_{-}$target } & \multicolumn{3}{|c|}{$\pi_{-}$target } & \multicolumn{3}{|c|}{$\pi_{-}$target } \\
\hline const & $\begin{array}{c}1.609^{* * *} \\
{[0.298]}\end{array}$ & $\begin{array}{c}1.757^{* * *} \\
{[0.288]}\end{array}$ & $\begin{array}{l}1.542^{* * *} \\
{[0.298]}\end{array}$ & $\begin{array}{c}1.540^{* * *} \\
{[0.391]}\end{array}$ & $\begin{array}{c}1.669 \\
{[1.106]}\end{array}$ & $\begin{array}{c}1.525 \\
{[1.038]}\end{array}$ & $\begin{array}{l}1.593^{* * *} \\
{[0.268]}\end{array}$ & $\begin{array}{c}1.683^{* * *} \\
{[0.262]}\end{array}$ & $\begin{array}{l}1.514^{* * *} \\
{[0.270]}\end{array}$ & $\begin{array}{l}1.582^{* * *} \\
{[0.299]}\end{array}$ & $\begin{array}{l}1.718^{* *} \\
{[0.755]}\end{array}$ & $\begin{array}{c}1.510^{* * *} \\
{[0.343]}\end{array}$ \\
\hline$\pi_{-}$target $_{-1}$ & $\begin{array}{c}0.336 * * * \\
{[0.070]}\end{array}$ & $\begin{array}{c}0.186^{*} \\
{[0.101]}\end{array}$ & $\begin{array}{l}0.311^{* * *} \\
{[0.072]}\end{array}$ & $\begin{array}{l}0.340^{* *} \\
{[0.143]}\end{array}$ & $\begin{array}{c}0.168 \\
{[0.359]}\end{array}$ & $\begin{array}{c}0.308 \\
{[0.200]}\end{array}$ & $\begin{array}{c}0.377^{* * *} \\
{[0.061]}\end{array}$ & $\begin{array}{c}0.255^{* * *} \\
{[0.089]}\end{array}$ & $\begin{array}{c}0.356^{* * *} \\
{[0.063]}\end{array}$ & $\begin{array}{c}0.384^{* * *} \\
{[0.100]}\end{array}$ & $\begin{array}{c}0.222^{*} \\
{[0.116]}\end{array}$ & $\begin{array}{c}0.358^{* * *} \\
{[0.113]}\end{array}$ \\
\hline$\pi \_p a s t 1^{2)}$ & $\begin{array}{c}0.212^{* * *} \\
{[0.046]}\end{array}$ & & & $\begin{array}{l}0.205^{* *} \\
{[0.104]}\end{array}$ & & & $\begin{array}{l}0.179 * * * \\
{[0.044]}\end{array}$ & & & $\begin{array}{c}0.172^{*} \\
{[0.090]}\end{array}$ & & \\
\hline$\pi \_$past $2^{2)}$ & & $\begin{array}{c}0.302^{* * *} \\
{[0.076]}\end{array}$ & & & $\begin{array}{l}0.309^{* *} \\
{[0.139]}\end{array}$ & & & $\begin{array}{c}0.257^{* * *} \\
{[0.072]}\end{array}$ & & & $\begin{array}{l}0.268^{* *} \\
{[0.133]}\end{array}$ & \\
\hline$\pi \_$past $3^{2)}$ & & & $\begin{array}{c}0.240^{* * *} \\
{[0.051]}\end{array}$ & & & $\begin{array}{l}0.243^{* *} \\
{[0.096]}\end{array}$ & & & $\begin{array}{c}0.207^{* * *} \\
{[0.049]}\end{array}$ & & & $\begin{array}{l}0.206^{* *} \\
{[0.097]}\end{array}$ \\
\hline observations & 103 & 103 & 103 & 103 & 103 & 103 & 121 & 121 & 121 & 121 & 121 & 121 \\
\hline $\begin{array}{l}\text { number of } \\
\text { instrumental } \\
\text { variables }\end{array}$ & 58 & 58 & 58 & 58 & 58 & 58 & 75 & 75 & 75 & 75 & 75 & 75 \\
\hline
\end{tabular}

Notes: 1) Standard errors are in brackets. ${ }^{*} * *, * * *$ mean that the estimates are significant at the $10 \%, 5 \%$, and $1 \%$ significance levels respectively.

2) $\pi_{-}$past 1 is the inflation rate of the previous one year, $\pi_{-}$past 2 is the average inflation rate of the past two years, and $\pi_{-}$past 3 is the average inflation rate for the past target horizon.

3) Windmeijer (2005) bias-corrected robust standard errors are reported. 
Table A4: The Role of Targeting Performance - GMM Estimation Result (Equation (2))

(Countries with high performance)

\begin{tabular}{|c|c|c|c|c|c|c|c|c|c|c|c|c|}
\hline & \multicolumn{6}{|c|}{ First Difference GMM } & \multicolumn{6}{|c|}{ System GMM } \\
\hline & \multicolumn{3}{|c|}{ One Step GMM } & \multicolumn{3}{|c|}{ Two Step GMM3) } & \multicolumn{3}{|c|}{ One Step GMM } & \multicolumn{3}{|c|}{ Two Step GMM3) } \\
\hline & \multicolumn{3}{|c|}{$\pi_{-}$target } & \multicolumn{3}{|c|}{$\pi_{-}$target } & \multicolumn{3}{|c|}{$\pi_{-}$target } & \multicolumn{3}{|c|}{$\pi_{-}$target } \\
\hline const & $\begin{array}{c}0.932^{* * *} \\
{[0.258]}\end{array}$ & $\begin{array}{l}0.714^{* *} \\
{[0.316]}\end{array}$ & $\begin{array}{c}0.935^{* * *} \\
{[0.253]}\end{array}$ & $\begin{array}{c}0.864^{* * *} \\
{[0.309]}\end{array}$ & $\begin{array}{c}0.623 \\
{[1.171]}\end{array}$ & $\begin{array}{c}0.828^{* * *} \\
{[0.320]}\end{array}$ & $\begin{array}{c}0.674^{* * *} \\
{[0.249]}\end{array}$ & $\begin{array}{c}0.523^{*} \\
{[0.303]}\end{array}$ & $\begin{array}{c}0.687^{* * *} \\
{[0.246]}\end{array}$ & $\begin{array}{l}0.650^{* *} \\
{[0.282]}\end{array}$ & $\begin{array}{c}0.566 \\
{[0.826]}\end{array}$ & $\begin{array}{l}0.641^{* *} \\
{[0.250]}\end{array}$ \\
\hline$\pi_{-}$target $_{-1}$ & $\begin{array}{l}0.579 * * * \\
{[0.0990]}\end{array}$ & $\begin{array}{c}0.799^{* * *} \\
{[0.138]}\end{array}$ & $\begin{array}{c}0.554^{* * *} \\
{[0.102]}\end{array}$ & $\begin{array}{l}0.548^{* *} \\
{[0.257]}\end{array}$ & $\begin{array}{c}0.770 \\
{[0.567]}\end{array}$ & $\begin{array}{c}0.531^{* * *} \\
{[0.183]}\end{array}$ & $\begin{array}{c}0.619^{* * *} \\
{[0.093]}\end{array}$ & $\begin{array}{c}0.796^{* * *} \\
{[0.133]}\end{array}$ & $\begin{array}{c}0.582^{* * *} \\
{[0.099]}\end{array}$ & $\begin{array}{c}0.551^{* * *} \\
{[0.094]}\end{array}$ & $\begin{array}{c}0.722 \\
{[0.493]}\end{array}$ & $\begin{array}{c}0.548^{* * *} \\
{[0.196]}\end{array}$ \\
\hline$\pi_{-}$past $1^{2)}$ & $\begin{array}{c}0.093 \\
{[0.074]}\end{array}$ & & & $\begin{array}{c}0.124 \\
{[0.220]}\end{array}$ & & & $\begin{array}{c}0.103 \\
{[0.071]}\end{array}$ & & & $\begin{array}{c}0.169^{*} \\
{[0.096]}\end{array}$ & & \\
\hline$\pi_{-}$past $2^{2)}$ & & $\begin{array}{l}-0.073 \\
{[0.084]}\end{array}$ & & & $\begin{array}{l}-0.035 \\
{[0.287]}\end{array}$ & & & $\begin{array}{l}-0.038 \\
{[0.082]}\end{array}$ & & & $\begin{array}{c}0.019 \\
{[0.274]}\end{array}$ & \\
\hline$\pi_{-}$past $3^{2)}$ & & & $\begin{array}{c}0.114 \\
{[0.077]}\end{array}$ & & & $\begin{array}{c}0.143 \\
{[0.166]}\end{array}$ & & & $\begin{array}{c}0.133^{*} \\
{[0.076]}\end{array}$ & & & $\begin{array}{c}0.166 \\
{[0.166]}\end{array}$ \\
\hline observations & 68 & 68 & 68 & 68 & 68 & 68 & 78 & 78 & 78 & 78 & 78 & 78 \\
\hline $\begin{array}{l}\text { number of } \\
\text { instrumental } \\
\text { variables }\end{array}$ & 40 & 40 & 40 & 40 & 40 & 40 & 50 & 50 & 50 & 50 & 50 & 50 \\
\hline
\end{tabular}

Notes: 1) Standard errors are in brackets. ${ }^{*}, * *, * *$ mean that the estimates are significant at the $10 \%, 5 \%$, and $1 \%$ significance levels respectively. 2) $\pi_{-}$past 1 is the inflation rate of the previous one year, $\pi_{-}$past 2 is the average inflation rate of the past two years, and $\pi_{-}$past 3 is the average inflation rate for the past target horizon.

3) Windmeijer (2005) bias-corrected robust standard errors are reported. 
(Countries with low performance)

\begin{tabular}{|c|c|c|c|c|c|c|c|c|c|c|c|c|}
\hline & \multicolumn{6}{|c|}{ First Difference GMM } & \multicolumn{6}{|c|}{ System GMM } \\
\hline & \multicolumn{3}{|c|}{ One Step GMM } & \multicolumn{3}{|c|}{ Two Step GMM3) } & \multicolumn{3}{|c|}{ One Step GMM } & \multicolumn{3}{|c|}{ Two Step GMM3) } \\
\hline const & $\begin{array}{c}1.696^{* * *} \\
{[0.267]}\end{array}$ & $\begin{array}{c}1.474^{* * *} \\
{[0.302]}\end{array}$ & $\begin{array}{c}1.625^{* * *} \\
{[0.290]}\end{array}$ & $\begin{array}{c}1.541^{* * *} \\
{[0.583]}\end{array}$ & $\begin{array}{l}1.449^{* *} \\
{[0.730]}\end{array}$ & $\begin{array}{c}1.439 \\
{[1.171]}\end{array}$ & $\begin{array}{c}1.774^{* * *} \\
{[0.261]}\end{array}$ & $\begin{array}{c}1.682^{* * *} \\
{[0.280]}\end{array}$ & $\begin{array}{c}1.721^{* * *} \\
{[0.273]}\end{array}$ & $\begin{array}{c}1.679^{* * *} \\
{[0.525]}\end{array}$ & $\begin{array}{l}1.622^{* *} \\
{[0.693]}\end{array}$ & $\begin{array}{c}1.406 \\
{[1.618]}\end{array}$ \\
\hline$\pi_{-}$target $_{-1}$ & $\begin{array}{c}0.370^{* * *} \\
{[0.061]}\end{array}$ & $\begin{array}{c}0.417^{* * *} \\
{[0.053]}\end{array}$ & $\begin{array}{c}0.393^{* * *} \\
{[0.067]}\end{array}$ & $\begin{array}{l}0.380^{* *} \\
{[0.184]}\end{array}$ & $\begin{array}{c}0.414^{*} \\
{[0.229]}\end{array}$ & $\begin{array}{c}0.407 \\
{[0.420]}\end{array}$ & $\begin{array}{c}0.433^{* * *} \\
{[0.057]}\end{array}$ & $\begin{array}{c}0.466 * * * \\
{[0.051]}\end{array}$ & $\begin{array}{c}0.435^{* * * *} \\
{[0.062]}\end{array}$ & $\begin{array}{l}0.432^{* *} \\
{[0.189]}\end{array}$ & $\begin{array}{l}0.464^{* *} \\
{[0.192]}\end{array}$ & $\begin{array}{c}0.462 \\
{[0.437]}\end{array}$ \\
\hline$\pi_{-}$past $1^{2)}$ & $\begin{array}{c}0.236 * * * \\
{[0.051]}\end{array}$ & & & $\begin{array}{l}0.223^{*} \\
{[0.127]}\end{array}$ & & & $\begin{array}{c}0.177^{* * *} \\
{[0.046]}\end{array}$ & & & $\begin{array}{c}0.174 \\
{[0.117]}\end{array}$ & & \\
\hline$\pi \_$past $2^{2)}$ & & $\begin{array}{c}0.209^{* * *} \\
{[0.045]}\end{array}$ & & & $\begin{array}{c}0.209 \\
{[0.144]}\end{array}$ & & & $\begin{array}{l}0.152^{* * *} \\
{[0.039]}\end{array}$ & & & $\begin{array}{c}0.156 \\
{[0.110]}\end{array}$ & \\
\hline$\pi \_p a s t 3^{2)}$ & & & $\begin{array}{c}0.220^{* * *} \\
{[0.057]}\end{array}$ & & & $\begin{array}{c}0.227 \\
{[0.272]}\end{array}$ & & & $\begin{array}{c}0.178^{* * *} \\
{[0.050]}\end{array}$ & & & $\begin{array}{c}0.186 \\
{[0.228]}\end{array}$ \\
\hline observations & 74 & 74 & 74 & 74 & 74 & 74 & 83 & 83 & 83 & 83 & 83 & 83 \\
\hline $\begin{array}{c}\text { number of } \\
\text { instrumental } \\
\text { variables }\end{array}$ & 49 & 49 & 49 & 49 & 49 & 49 & 66 & 66 & 66 & 66 & 66 & 66 \\
\hline
\end{tabular}

Notes: 1) Standard errors are in brackets. $,_{* *}, * * *$ mean that the estimates are significant at the $10 \%, 5 \%$, and $1 \%$ significance levels respectively. 2) $\pi_{-}$past 1 is the inflation rate of the previous one year, $\pi_{-}$past 2 is the average inflation rate of the past two years, and $\pi_{-}$past 3 is the average inflation rate for the past target horizon.

3) Windmeijer (2005) bias-corrected robust standard errors are reported. 
Table A5: Performance Indicator and Country Group

\begin{tabular}{|c|c|c|}
\hline Country & Performance Indicator & Group \\
\hline Thailand & 1.1 & High \\
\hline Canada & 1.1 & High \\
\hline Korea & 1.7 & High \\
\hline Peru & 2.7 & High \\
\hline New Zealand & 3.0 & High \\
\hline Philippines & 3.8 & High \\
\hline Poland & 3.8 & High \\
\hline Czech & 4.1 & High \\
\hline Israel & 6.0 & High \\
\hline Chile & 6.4 & High \\
\hline Hungary & 6.5 & Low \\
\hline Romania & 6.6 & Low \\
\hline Colombia & 8.1 & Low \\
\hline Guatemala & 8.5 & Low \\
\hline Indonesia & 12.0 & Low \\
\hline Brazil & 12.7 & Low \\
\hline Ghana & 27.6 & Low \\
\hline Mexico & 29.1 & Low \\
\hline Turkey & 40.4 & Low \\
\hline Average & 6.9 & - \\
\hline
\end{tabular}

Note: 1) "High" and "Low" indicate high and low performance group respectively. 


\section{물가목표의 내생성}

\section{김소영*, 임근형**}

물가안정목표제 하에서 중앙은행들은 원칙적으로 물가목표를 선제적으로 설정하고 난 후 실제 인플레이션이 물가목표와 근접하도록 통화정책을 운영하 게 된다. 하지만 현실적으로는 실제 인플레이션과 물가목표 간의 괴리를 해소 하기 위해 물가목표를 과거 인플레이션에 부합하는 수준에서 설정하려는 유인 이 존재할 가능성이 있다. 본고는 물가안정목표제를 운영 중인 19 개 국가를 대 상으로 물가목표 설정 과정에 있어서의 내생성 존재 여부를 다양한 실증분석 방법을 통해 살펴보았다. 실증분석 결과 실제 인플레이션이 다음 기의 물가목 표 설정에 유의한 영향을 미치는 것으로 나타났다. 뿐만 아니라 물가목표 달성 성과가 낮거나 평판이 좋지 않은 중앙은행일수록 실제 인플레이션 움직임을 뒤따라 물가목표를 조정하는 성향이 강한 것으로 분석되었다.

핵심 주제어: 물가안정목표제, 인플레이션, 물가목표, 내생성

JEL Classification: E31, E58

* 서울대학교 경제학부 교수 (전화: 02-880-2689, E-mail: soyoungkim@snu.ac.kr)

** 한국은행 경제 연구원 거시경제연구실 부연구위원 (전화: 02-759-5349, E-mail: ghyim@bok.or.kr)

본 연구내용은 집필자의 개인의견이며 한국은행의 공식견해와는 무관합니다. 따라서 본 논문의 내용을 보도하거나 인용할 경우에는 집필자 명을 반드시 명시하여 주시기 바랍니다. 


\section{$\mathrm{BOK}$ 경제연구 발간목록}

한국은행 경제연구원에서는 Working Paper인 『BOK 경제연구』를 수시로 발간하고 있습니다. ${ }^{\circledR B O K}$ 경제연구』는 주요 경제 현상 및 정책 효과에 대한 직관적 설명 뿐 아니라 깊이 있는 이론 또는 실증 분석을 제공함으로써 엄밀한 논증에 초점을 두는 학술논문 형태의 연구이며 한국은행 직원 및 한국은행 연구용역사업의 연구 결과물이 수록되고 있습니다.

${ }^{『} \mathrm{BOK}$ 경제연구』는 한국은행 경제연구원 홈페이지(http://imer.bok.or.kr)에서 다운로드하여 보실 수 있습니다.

제2014-1 Network Indicators for Monitoring Intraday Liquidity in BOK-Wire+

2 중소기업에 대한 신용정책 효과

3 경제충격 효과의 산업간 공행성 분석

4 서비스업 발전을 통한 내외수 균형성장: 기대효과 및 리스크

5 Cross-country-heterogeneous and Time-varying Effects of Unconventional Monetary Policies in AEs on Portfolio Inflows to EMEs

6 인터넷뱅킹, 결제성예금 및 은행 수익성과의 관계 분석

7 Dissecting Foreign Bank Lending Behavior During the 2008-2009 Crisis

8 The Impact of Foreign Banks on Monetary Policy Transmission during the Global Financial Crisis of 2008-2009: Evidence from Korea

9 Welfare Cost of Business Cycles in Economies with Individual Consumption Risk

10 Investor Trading Behavior Around the Time of Geopolitical Risk Events: Evidence from South Korea

11 Imported-Inputs Channel of Exchange Rate Pass-Through: Evidence from Korean Firm-Level Pricing Survey
Seungjin Baek •

Kimmo Soram ki • Jaeho Yoon

정호성·임호성

황선웅·민성환 ·

신동현 · 김기호

김승원 · 황광명

Kyoungsoo Yoon •

Christophe Hurlin

이동규·전봉걸

Moon Jung Choi •

Eva Gutierrez •

Maria Soledad Martinez Peria

Bang Nam Jeon •

Hosung Lim • Ji Wu

Martin Ellison •

Thomas J. Sargent

Young Han Kim • Hosung Jung

Jae Bin Ahn •

Chang-Gui Park 


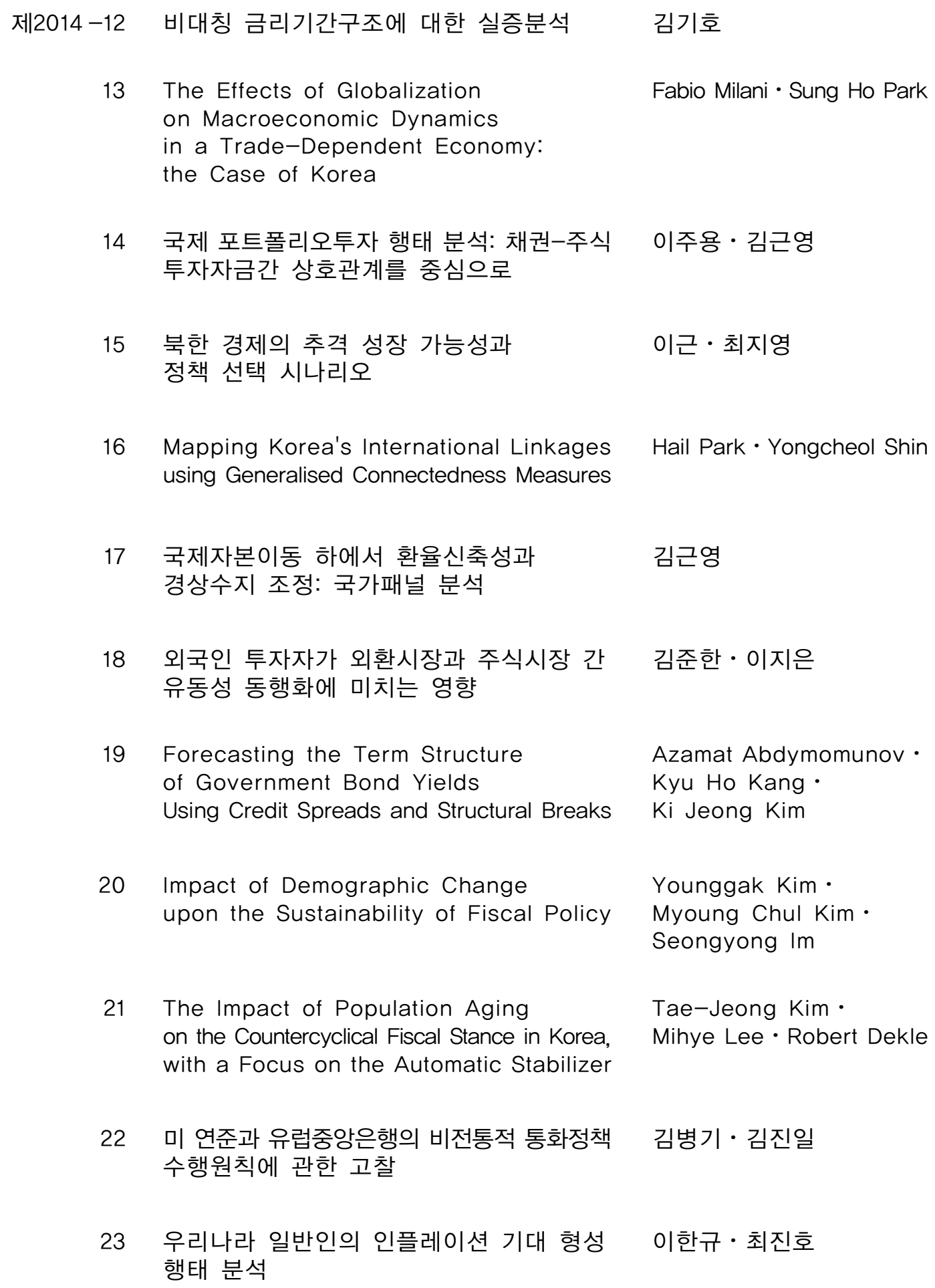

22 미 연준과 유럽중앙은행의 비전통적 통화정책 수행원칙에 관한 고찰

23 우리나라 일반인의 인플레이션 기대 형성 행태 분석

Fabio Milani · Sung Ho Park

이주용·김근영

이근 · 최지영

Hail Park $\cdot$ Yongcheol Shin

김근영

김준한·이지은

Azamat Abdymomunov . Kyu Ho Kang •

$\mathrm{Ki}$ Jeong Kim

Younggak Kim $\cdot$

Myoung Chul Kim.

Seongyong Im

Tae-Jeong Kim •

Mihye Lee $\cdot$ Robert Dekle

김병기·김진일

이한규-최진호 


\section{제2014-24 Nonlinearity in Nexus between Working Hours and Productivity \\ Strategies for Reforming Korea's Labor Market to Foster Growth}

글로벌 금융위기 이후 성장잠재력 확충: 2014 한국은행 국제컨퍼런스 결과보고서

인구구조 변화가 경제성장률에 미치는 영향: 자본이동의 역할에 대한 논의를 중심으로

\section{Safe Assets}

확장된 실업지표를 이용한

우리나라 노동시장에서의 이력현상 분석

Entropy of Global Financial Linkages

International Currencies Past, Present and Future: Two Views from Economic History

금융체제 이행 및 통합 사례:

남북한 금융통합에 대한 시사점

Measuring Price-Level Uncertainty and Instability in the U.S., 1850-2012

고용보호제도가 노동시장 이원화

및 노동생산성에 미치는 영향

해외충격시 외화예금의 역할 : 주요 신흥국 신용스프레드에 미치는 영향을 중심으로

실업률을 고려한 최적 통화정책 분석

우리나라 무역거래의 결제통화 결정요인 분석

Global Liquidity Transmission to

Emerging Market Economies, and Their Policy Responses
Dongyeol Lee $\cdot$

Hyunjoon Lim

Mai Dao - Davide Furceri -

Jisoo Hwang .

Meeyeon Kim •

Tae-Jeong Kim

한국은행 경제연구원

손종칠

Robert J. Barro

김현학·황광명

Daeyup Lee

Barry Eichengreen

김병연

Timothy Cogley •

Thomas J. Sargent

김승원

정호성·우준명

김인수·이명수

황광명 · 김경민 ·

노충식·김미진

Woon Gyu Choi ·

Taesu Kang •

Geun-Young Kim •

Byongju Lee 
제2015-1 글로벌 금융위기 이후 주요국

통화정책 운영체계의 변화

2 미국 장기시장금리 변동이 우리나라 금리기간구조에 미치는 영향 분석 및 정책적 시사점

3 직간접 무역연계성을 통한 해외충격의 우리나라 수출입 파급효과 분석

4 통화정책 효과의 지역적 차이

5 수입중간재의 비용효과를 고려한 환율변동과 수출가격 간의 관계

6 중앙은행의 정책금리 발표가 주식시장 유동성에 미치는 영향

7 은행 건전성지표의 변동요인과 거시건전성 규제의 영향

8 Price Discovery and Foreign Participation in The Republic of Korea's Government Bond Futures and Cash Markets

9 규제가 노동생산성에 미치는 영향: 한국의 산업패널 자료를 이용한 실증분석

10 인구 고령화와 정년연장 연구 (세대 간 중첩모형(OLG)을 이용한 정량 분석)

11 예측조합 및 밀도함수에 의한 소비자물가 상승률 전망

인플레이션 동학과 통화정책

Failure Risk and the Cross-Section of Hedge Fund Returns

Global Liquidity and Commodity Prices

15
Foreign Ownership, Legal System and Stock Market Liquidity
김병기·김인수

강규호·오형석

최문정·김근영

김기호

김경민

이지은

강종구

Jaehun Choi · Hosung Lim •

Rogelio Jr. Mercado •

Cyn-Young Park

이동렬·최종일·이종한

홍재화·강태수

김현학

우준명

Jung-Min Kim

Hyunju Kang •

Bok-Keun $\mathrm{Yu}$.

Jongmin $\mathrm{Yu}$

Jieun Lee $\cdot$ Kee H. Chung 


\begin{tabular}{|c|c|c|}
\hline 제2015-16 & $\begin{array}{l}\text { 바젤 III 은행 경기대응완충자본 규제의 } \\
\text { 기준지표에 대한 연구 }\end{array}$ & 서현덕·이정연 \\
\hline 17 & 우리나라 대출 수요와 공급의 변동요인 분석 & 강종구·임호성 \\
\hline 18 & 북한 인구구조의 변화 추이와 시사점 & 최지영 \\
\hline 19 & $\begin{array}{l}\text { Entry of Non-financial Firms and Competition } \\
\text { in the Retail Payments Market }\end{array}$ & Jooyong Jun \\
\hline 20 & $\begin{array}{l}\text { Monetary Policy Regime Change } \\
\text { and Regional Inflation Dynamics: } \\
\text { Looking through the Lens of } \\
\text { Sector-Level Data for Korea }\end{array}$ & $\begin{array}{l}\text { Chi-Young Choi } \\
\text { Joo Yong Lee } \\
\text { Roisin O'Sullivan }\end{array}$ \\
\hline 21 & $\begin{array}{l}\text { Costs of Foreign Capital Flows } \\
\text { in Emerging Market Economies: } \\
\text { Unexpected Economic Growth } \\
\text { and Increased Financial Market Volatility }\end{array}$ & $\begin{array}{l}\text { Kyoungsoo Yoon. } \\
\text { Jayoung Kim }\end{array}$ \\
\hline 22 & $\begin{array}{l}\text { 글로벌 금리 정상화와 통화정책 과제: } \\
\text { 2015년 한국은행 국제컨퍼런스 결과보고서 }\end{array}$ & 한국은행 경제연구원 \\
\hline 23 & $\begin{array}{l}\text { The Effects of Global Liquidity } \\
\text { on Global Imbalances }\end{array}$ & $\begin{array}{l}\text { Marie-Louise DJIGBENOU-KRE · } \\
\text { Hail Park }\end{array}$ \\
\hline 24 & 실물경기를 고려한 내재 유동성 측정 & 우준명·이지은 \\
\hline 25 & Deflation and Monetary Policy & Barry Eichengreen \\
\hline 26 & $\begin{array}{l}\text { Macroeconomic Shocks } \\
\text { and Dynamics of Labor Markets in Korea }\end{array}$ & $\begin{array}{l}\text { Tae Bong Kim } \cdot \\
\text { Hangyu Lee }\end{array}$ \\
\hline 27 & $\begin{array}{l}\text { Reference Rates and Monetary Policy } \\
\text { Effectiveness in Korea }\end{array}$ & $\begin{array}{l}\text { Heung Soon Jung } \\
\text { Dong Jin Lee } \\
\text { Tae Hyo Gwon. } \\
\text { Se Jin Yun }\end{array}$ \\
\hline 28 & Energy Efficiency and Firm Growth & $\begin{array}{l}\text { Bongseok Choi } \\
\text { Wooyoung Park } \\
\text { Bok-Keun Yu }\end{array}$ \\
\hline 29 & $\begin{array}{l}\text { An Analysis of Trade Patterns } \\
\text { in East Asia and the Effects of } \\
\text { the Real Exchange Rate Movements }\end{array}$ & $\begin{array}{l}\text { Moon Jung Choi } \\
\text { Geun-Young Kim } \\
\text { Joo Yong Lee }\end{array}$ \\
\hline 30 & $\begin{array}{l}\text { Forecasting Financial Stress Indices in } \\
\text { Korea: A Factor Model Approach }\end{array}$ & $\begin{array}{l}\text { Hyeongwoo Kim } \\
\text { Hyun Hak Kim• } \\
\text { Wen Shi }\end{array}$ \\
\hline
\end{tabular}


제2016-1 The Spillover Effects of U.S. Monetary Policy on Emerging Market Economies: Breaks, Asymmetries and Fundamentals

2 Pass-Through of Imported Input Prices to Domestic Producer Prices: Evidence from Sector-Level Data

3 Spillovers from U.S. Unconventional Monetary Policy and Its Normalization to Emerging Markets: A Capital Flow Perspective

4 Stock Returns and Mutual Fund Flows in the Korean Financial Market:

A System Approach

5 정책금리 변동이 성별·세대별 고용률에 미치는 영향

6 From Firm-level Imports to Aggregate Productivity: Evidence from Korean Manufacturing Firms Data

7 자유무역협정(FTA)이 한국 기업의 기업내 무역에 미친 효과

8 The Relation Between Monetary and Macroprudential Policy

9 조세피난처 투자자가 투자 기업 및 주식 시장에 미치는 영향

10 주택실거래 자료를 이용한 주택부문 거시 건전성 정책 효과 분석

11 Does Intra-Regional Trade Matter in Regional Stock Markets?: New Evidence from Asia-Pacific Region

12 Liability, Information, and Anti-fraud Investment in a Layered Retail Payment Structure

Testing the Labor Market Dualism in Korea
Geun-Young Kim •

Hail Park •

Peter Tillmann

JaeBin Ahn •

Chang-Gui Park •

Chanho Park

Sangwon Suh

Byung-Soo Koo

Jaebeom Kim •

Jung-Min Kim

정성엽

JaeBin Ahn •

Moon Jung Choi

전봉걸·김은숙 · 이주용

Jong Ku Kang

정호성·김순호

정호성·이지은

Sei-Wan Kim • Moon Jung Choi

Kyoung-Soo Yoon • Jooyong Jun

Sungyup Chung •

Sunyoung Jung

최지영 비공식부문 분석 
제2016-15 Divergent EME Responses to Global and Domestic Monetary Policy Shocks

16

Loan Rate Differences across Financial Sectors: A Mechanism Design Approach

17 근로자의 고용형태가 임금 및 소득 분포 에 미치는 영향

18 Endogeneity of Inflation Target
Woon Gyu Choi ·

Byongju Lee .

Taesu Kang •

Geun-Young Kim

Byoung-Ki Kim • Jun Gyu Min

최충·정성엽

Soyoung Kim •

Geunhyung Yim 